\title{
Enrichment, isolation, and characterization of high-affinity N2O-reducing bacteria in a gas-permeable membrane reactor
}

Suenaga, Toshikazu; Hori, Tomoyuki; Riya, Shohei; Hosomi, Masaaki; Smets, Barth F.; Terada, Akihiko

Published in:

Environmental Science and Technology

Link to article, DOI:

10.1021/acs.est.9b02237

Publication date:

2019

Document Version

Peer reviewed version

Link back to DTU Orbit

Citation (APA):

Suenaga, T., Hori, T., Riya, S., Hosomi, M., Smets, B. F., \& Terada, A. (2019). Enrichment, isolation, and characterization of high-affinity $\mathrm{N}_{2} \mathrm{O}$-reducing bacteria in a gas-permeable membrane reactor. Environmental Science and Technology, 53, 12101-12112. https://doi.org/10.1021/acs.est.9b02237

\section{General rights}

Copyright and moral rights for the publications made accessible in the public portal are retained by the authors and/or other copyright owners and it is a condition of accessing publications that users recognise and abide by the legal requirements associated with these rights.

- Users may download and print one copy of any publication from the public portal for the purpose of private study or research.

- You may not further distribute the material or use it for any profit-making activity or commercial gain

- You may freely distribute the URL identifying the publication in the public portal 
This document is confidential and is proprietary to the American Chemical Society and its authors. Do not copy or disclose without written permission. If you have received this item in error, notify the sender and delete all copies.

\section{Enrichment, isolation, and characterization of high-affinity $\mathrm{N}_{2} \mathrm{O}$-reducing bacteria in a gas-permeable membrane reactor}

\begin{tabular}{|r|l|}
\hline Journal: & Environmental Science \& Technology \\
\hline Manuscript ID & es-2019-022378.R1 \\
\hline Danuscript Type: & Article \\
\hline Author: & 23-Aug-2019 \\
\hline Complete List of Authors: & $\begin{array}{l}\text { Suenaga, Toshikazu; Tokyo University of Agriculture and Technology, } \\
\text { Chemical Engineering } \\
\text { Hori, Tomoyuki; National Institute of Advanced Industrial Science and } \\
\text { Technology (AIST), } \\
\text { Riya, Shohei; Tokyo Noko Daigaku, Chemical Engineering } \\
\text { Hosomi, Masaaki; Tokyo University of Agriculture and Technology, } \\
\text { Chemical Engineering } \\
\text { Smets, Barth F.; Technical University of Denmark, Environmental } \\
\text { Engineering } \\
\text { Terada, Akihiko; Tokyo University of Agriculture and Technology, } \\
\text { Chemical Engineering }\end{array}$ \\
\hline
\end{tabular}

\section{SCHOLARONE Manuscripts}




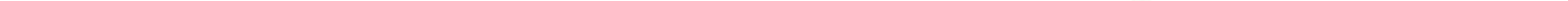


Manuscript submitted to Environmental Science and Technology (Research article)

Enrichment, isolation, and characterization of high-affinity $\mathrm{N}_{2} \mathrm{O}$-reducing bacteria in a gas-permeable membrane reactor

Running title: Enrichment and isolation of high-affinity $\mathrm{N}_{2} \mathrm{O}$ reducers

Toshikazu Suenaga ${ }^{1,2}$, Tomoyuki Hori ${ }^{3}$, Shohei Riya ${ }^{1,2}$, Masaaki Hosomi ${ }^{1}$, Barth F. Smets ${ }^{2,4}$, Akihiko Terada $^{1,2 *}$

${ }^{1}$ Department of Chemical Engineering, Tokyo University of Agriculture and Technology, 2-24-16 Naka-cho, Koganei, Tokyo, 184-8588, Japan

${ }^{2}$ Institute of Global Innovation Research, Tokyo University of Agriculture and Technology, 3-8-1 Harumi-cho, Fuchu, Tokyo, 185-8538, Japan

${ }^{3}$ Environmental Management Research Institute, National Institute of Advanced Industrial Science and Technology (AIST), Onogawa 16-1, Tsukuba, Ibaraki 305-8569, Japan

${ }^{4}$ Department of Environmental Engineering, Technical University of Denmark, Miljoevej, 2800 Lyngby, Denmark

Corresponding: A. Terada (Email: akte@cc.tuat.ac.jp; Tel: +81-42-388-7069) 


\section{$1 \quad$ Abstract}

2 The recent discovery of nitrous oxide $\left(\mathrm{N}_{2} \mathrm{O}\right)$-reducing bacteria suggests a potential biological 3 sink for the potent greenhouse gas $\mathrm{N}_{2} \mathrm{O}$. For an application towards $\mathrm{N}_{2} \mathrm{O}$ mitigation, characterization of more isolates will be required. Here, we describe the successful enrichment and isolation of high-affinity $\mathrm{N}_{2} \mathrm{O}$-reducing bacteria using an $\mathrm{N}_{2} \mathrm{O}$-fed reactor $\left(\mathrm{N}_{2} \mathrm{OFR}\right)$. Two $\mathrm{N}_{2} \mathrm{OFRs}$, where $\mathrm{N}_{2} \mathrm{O}$ was continuously and directly supplied as the sole electron acceptor to a biofilm grown on a gas-permeable membrane, were operated with acetate or a mixture of peptone-based organic substrates as an electron donor. In parallel, a $\mathrm{NO}_{3}{ }^{-}$-fed reactor $\left(\mathrm{NO}_{3} \mathrm{FR}\right)$, filled with a non-woven sheet substratum, was operated using the same inoculum. We hypothesized that supplying $\mathrm{N}_{2} \mathrm{O}$ vs. $\mathrm{NO}_{3}{ }^{-}$would enhance the dominance of distinct $\mathrm{N}_{2} \mathrm{O}-$ reducing bacteria. Clade II type nos $Z$ bacteria became rapidly enriched over clade I type nos $Z$ bacteria in the $\mathrm{N}_{2} \mathrm{OFRs}$ whereas the opposite held in the $\mathrm{NO}_{3} \mathrm{FR}$. High-throughput sequencing of 16S rRNA gene amplicons revealed the dominance of Rhodocyclaceae in the $\mathrm{N}_{2} \mathrm{OFRs}$. Strains of the Azospira and Dechloromonas genera, canonical denitrifiers harboring clade II type $\operatorname{nos} Z$, were isolated with high frequency from the $\mathrm{N}_{2}$ OFRs (132 out of 152 isolates). The isolates from the $\mathrm{N}_{2} \mathrm{OFR}$ demonstrated higher $\mathrm{N}_{2} \mathrm{O}$ uptake rates $\left(V_{\max }: 4.23 \times 10^{-3}-1.80 \times 10^{-2}\right.$ $\mathrm{pmol} / \mathrm{h} / \mathrm{cell})$ and lower $\mathrm{N}_{2} \mathrm{O}$ half-saturation coefficients $\left(K_{\mathrm{m}, \mathrm{N} 2 \mathrm{O}}: 1.55-2.10 \mu \mathrm{M}\right)$ than a clade I type nos $Z$ isolate from the $\mathrm{NO}_{3} \mathrm{FR}$. Furthermore, the clade II type nos $Z$ isolates had higher specific growth rates on $\mathrm{N}_{2} \mathrm{O}$ than nitrite as an electron acceptor. Hence, continuously and exclusively supplying $\mathrm{N}_{2} \mathrm{O}$ in an $\mathrm{N}_{2} \mathrm{OFR}$ allows the enrichment and isolation of high-affinity $\mathrm{N}_{2} \mathrm{O}$-reducing strains, which may be used as $\mathrm{N}_{2} \mathrm{O}$ sinks in bioaugmentation efforts. 


\section{Introduction}

Nitrous oxide $\left(\mathrm{N}_{2} \mathrm{O}\right)$ emissions are a global concern as $\mathrm{N}_{2} \mathrm{O}$ is a potent greenhouse gas as well as a substance with ozone destruction potential ${ }^{1,2}$. Atmospheric $\mathrm{N}_{2} \mathrm{O}$ concentrations have increased at a rate of $0.75 \mathrm{ppb} / \mathrm{year}$ during the last century ${ }^{3}$ and are expected to increase further. Biological nitrogen removal in wastewater treatment plants (WWTPs) has drawn attention as $\mathrm{N}_{2} \mathrm{O}$ emissions are more substantial than initially expected ${ }^{4} \cdot \mathrm{N}_{2} \mathrm{O}$ is produced as a byproduct of ammonia oxidation mediated by ammonia-oxidizing autotrophic microorganisms ${ }^{5}$ and is an obligatory intermediate in denitrification mediated by heterotrophic microorganisms. Studies on the mechanisms of $\mathrm{N}_{2} \mathrm{O}$ production ${ }^{6-9}$ and the quantification of $\mathrm{N}_{2} \mathrm{O}$ emissions from various treatment bioreactors ${ }^{10-12}$ abound. Whereas these studies have substantially advanced our knowledge, it should be noted that $\mathrm{N}_{2} \mathrm{O}$ emissions are the net effect of production and consumption, and a comprehensive understanding of $\mathrm{N}_{2} \mathrm{O}$ consumption mechanisms awaits us. Community analyses based on $16 \mathrm{~S}_{\mathrm{rRNA}}{ }^{13}$ and functional gene encoding $\mathrm{N}_{2} \mathrm{O}$ reductase (nos $Z$ ) 14 have been performed to identify microorganisms responsible for $\mathrm{N}_{2} \mathrm{O}$ consumption in wastewater treatment bioreactors. Nevertheless, studies on $\mathrm{N}_{2} \mathrm{O}$ reducers in WWTPs have so far been limited ${ }^{15}$ and further research is necessary to broaden our knowledge of $\mathrm{N}_{2} \mathrm{O}$ reducers.

Previously, bacteria harboring the nos $Z$ gene, encoding NosZ, were considered canonical denitrifiers, which also catalyze nitrite (and often nitrate) reduction ${ }^{16}$. Genomic analyses of $\mathrm{N}_{2} \mathrm{O}$-reducing bacteria have revealed two distinct classes of nos $Z$ sequences, allowing for the classification of canonical denitrifiers into two distinct groups ${ }^{17,18}$. Most well-investigated canonical denitrifiers, e.g., the genera Bradyrhizobium, Pseudomonas, and Paracoccus, possess clade I type nosZ. The clade II type nos $Z$ is phylogenetically, being present in 14 bacterial phyla ${ }^{19}$, and is ubiquitous in natural environments ${ }^{17,20}$. In addition, non-denitrifying $\mathrm{N}_{2} \mathrm{O}$-reducing 
bacteria have recently been identified from soils and sediments ${ }^{17,18}$. They lack most denitrification enzymes except nitric oxide reductase (Nor) and NosZ, and most of them possess a clade II type nos $Z$ gene ${ }^{19}$. Such non-denitrifying $\mathrm{N}_{2} \mathrm{O}$ reducers, as well as canonical denitrifers with clade II type nosZ, potentially function as $\mathrm{N}_{2} \mathrm{O}$ sinks $15,18,19,21,22$.

$\mathrm{N}_{2} \mathrm{O}$-reducing bacteria that possess clade II type nos $Z$ may be better $\mathrm{N}_{2} \mathrm{O}$ consumers than those possessing clade I type nos $Z$, because former has a higher affinity for $\mathrm{N}_{2} \mathrm{O}$. Isolates carrying clade II type nosZ of the genera Dechloromonas and Anaeromyxobacter have lower $\mathrm{N}_{2} \mathrm{O}$ affinity constants $\left(K_{\mathrm{m}, \mathrm{N} 2 \mathrm{O}}=0.324\right.$ and $\left.1.34 \mu \mathrm{M}\right)$ than clade I type nos $Z$ isolates Pseudomonas stutzeri and Shewanella loihica $\left(K_{\mathrm{m}, \mathrm{N} 2 \mathrm{O}}=35.5\right.$ and $\left.7.07 \mu \mathrm{M}\right){ }^{23,24}$. However, the kinetics of $\mathrm{N}_{2} \mathrm{O}$ reduction have so far been examined for a limited set of isolates: the conclusion that clade II type nos $Z$ bacteria always display high affinity for $\mathrm{N}_{2} \mathrm{O}$ may be premature. Surprisingly, in a recent chemostat study, clade I type nos $Z$ bacteria remained dominant over clade II type nos $Z$ bacteria, irrespective of the electron donor or electron acceptor $\left(\mathrm{N}_{2} \mathrm{O}\right)$ limitation across the examined dilution rates ${ }^{25}$. In addition, in biofilters operated specifically for $\mathrm{N}_{2} \mathrm{O}$ mitigation, the predominant $\mathrm{N}_{2} \mathrm{O}$-reducing bacteria carried clade I type nos $Z$, and their abundances changed with different operating conditions ${ }^{26,27}$. Clearly, it is not yet fully established which $\mathrm{N}_{2} \mathrm{O}$-reducing bacteria are favored in which environments. Further exploration of $\mathrm{N}_{2} \mathrm{O}$ reducers is, therefore, needed.

For enriching $\mathrm{N}_{2} \mathrm{O}$-reducing bacteria, we used gas-permeable membrane biofilm reactors 28. The reactor is fed with $\mathrm{N}_{2} \mathrm{O}$ as a sole electron acceptor $\left(\mathrm{N}_{2} \mathrm{O}\right.$-fed reactor or $\left.\mathrm{N}_{2} \mathrm{OFR}\right)$ to enrich unexplored and/or high-affinity $\mathrm{N}_{2} \mathrm{O}$-reducing bacteria. In an $\mathrm{N}_{2} \mathrm{OFR}$ (Fig. 1), gaseous $\mathrm{N}_{2} \mathrm{O}$ is supplied via the membrane lumen directly to the biofilm grown on the outer membrane surface, which results in the countercurrent supply of $\mathrm{N}_{2} \mathrm{O}$ and the carbon substrates, provided via the 
aqueous phase ${ }^{29,30}$. We assume that the direct $\mathrm{N}_{2} \mathrm{O}$ supply to a biofilm onto a gas-permeable membrane without any bubbles would curb biofilm sloughing and the resultant washout of enriched bacteria ${ }^{31,32}$, ensuring the retention of diverse $\mathrm{N}_{2} \mathrm{O}$-reducing bacteria possessing various physiological traits in the biofilm without creating any liquid-gas interfaces. This property is distinct from chemostat-based enrichments where bacterial community composition is determined by a dilution rate ${ }^{25,33}$. In addition, a biofilm-based enrichment system would provide a range of niches along the biofilm depth. Whereas the biofilm base adjacent to the membrane receives high $\mathrm{N}_{2} \mathrm{O}$ concentration, the $\mathrm{N}_{2} \mathrm{O}$ concentration decreases towards the biofilm surface, providing a local environment where high-affinity $\mathrm{N}_{2} \mathrm{O}$ reducers thrive (Fig. 1) ${ }^{34}$. Such stratified environments may select for a range of $\mathrm{N}_{2} \mathrm{O}$-reducing bacteria, possessing various affinities for $\mathrm{N}_{2} \mathrm{O}$.

Hence, we investigated the feasibility to enrich $\mathrm{N}_{2} \mathrm{O}$-reducing bacteria in a gas-permeable membrane reactor by continuously supplying $\mathrm{N}_{2} \mathrm{O}\left(\mathrm{N}_{2} \mathrm{OFR}\right)$ and examined the enrichment yielded diverse or mainly high-affinity $\mathrm{N}_{2} \mathrm{O}$ reducers. In parallel with the $\mathrm{N}_{2} \mathrm{OFR}$, a biofilm reactor fed with nitrate $\left(\mathrm{NO}_{3} \mathrm{FR}\right)$ was operated to examine whether electron donor and acceptor types affect the selection of nos $Z$ clade types. The enrichment process was monitored by nos $Z$ targeted real-time qPCR and high-throughput sequencing of 16S rRNA gene amplicons, followed by the isolation of $\mathrm{N}_{2} \mathrm{O}$-reducing bacteria and examination of their $\mathrm{N}_{2} \mathrm{O}$ reduction activity.

\section{Materials and Methods}

\section{Enrichment reactors}

Two types of $\mathrm{N}_{2} \mathrm{O}$-fed reactors, one with acetate $\left(\mathrm{N}_{2} \mathrm{OFR} 1\right)$ and one with a peptone-based mixed 
substrate $\left(\mathrm{N}_{2} \mathrm{OFR} 2\right)$ as electron donor, and one $\mathrm{NO}_{3}{ }^{-}$-fed reactor, with the mixed substrate as electron donor $\left(\mathrm{NO}_{3} \mathrm{FR}\right)$, were continuously operated for 191 days. $\mathrm{N}_{2} \mathrm{OFRs}$ received $\mathrm{N}_{2} \mathrm{O}$ as a sole electron acceptor to enrich $\mathrm{N}_{2} \mathrm{O}$-reducing bacteria. $\mathrm{NO}_{3} \mathrm{FR}$ received $\mathrm{NO}_{3}{ }^{-}$as a sole electron acceptor to enrich canonical denitrifying bacteria. The volume of each enrichment reactor was consistently $94.2 \mathrm{~mL}$. During the operation, limiting and excess amounts of electron acceptors were supplied in Phases 1 (day 0 to 71 in $\mathrm{N}_{2} \mathrm{OFRs}$, day 0 to 38 in $\mathrm{NO}_{3} \mathrm{FR}$ ) and 2 (day 71 to 191 in $\mathrm{N}_{2} \mathrm{OFRs}$, day 0 to 38 in $\mathrm{NO}_{3} \mathrm{FR}$ ), respectively (Table 1). $\mathrm{N}_{2}$ OFRs contained a bundle of gaspermeable hollow fiber membranes (Model MHF 200TL, Mitsubishi Chemical Co. Inc., Tokyo, Japan) mounted in a cylindrical reactor (Fig. 1, SI), where the lumen was continuously flushed at $3 \mathrm{~mL} /$ min with an $\mathrm{N}_{2} \mathrm{O}: \mathrm{N}_{2}$ mixture. $\mathrm{N}_{2} \mathrm{O}$ loading rates were set by controlling the $\mathrm{N}_{2} \mathrm{O}$ partial

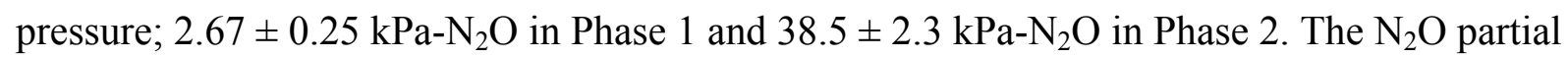
pressure was increased to enhance $\mathrm{N}_{2} \mathrm{O}$ transfer to the biofilms, developed on the gas-permeable membrane. The $\mathrm{N}_{2} \mathrm{O}$ supply rate was calculated based on the specific $\mathrm{N}_{2} \mathrm{O}$ transfer coefficient

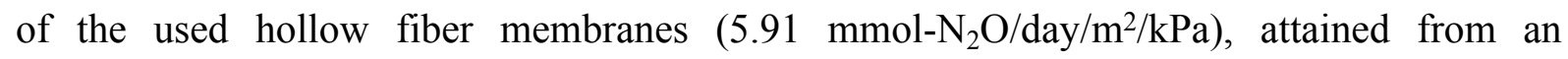
experiment following the previous study ${ }^{30}(\mathrm{SI})$. The expected $\mathrm{N}_{2} \mathrm{O}$ concentration in each phase in the absence of microorganism was estimated from the $\mathrm{N}_{2} \mathrm{O}$ partial pressure as detailed in Table 1. Electron balances in the enrichment reactors were calculated based on the supply rates of electron donors and acceptors as detailed in SI. This calculation assumes the respiration (but not fermentation) that electron donor is oxidized to $\mathrm{CO}_{2}$ whereas $\mathrm{NO}_{3}{ }^{-}$and $\mathrm{N}_{2} \mathrm{O}$ are reduced to $\mathrm{N}_{2}$. In the $\mathrm{NO}_{3} \mathrm{FR}$ a non-woven sheet of polyethylene (Nippon Vilene, Tokyo, Japan) ${ }^{35}$ served as a substratum for biofilm growth and nitrate was supplied via the liquid feed (Fig. S1). Hydraulic retention time (HRT) was 7 hours in all reactors. Each reactor was inoculated with $10 \mathrm{~mL}$ of biomass from a full-scale conventional activated sludge system treating municipal 
wastewater treatment (Tokyo Japan), containing, on average, $130 \mathrm{mg} / \mathrm{L}$ of BOD, $34 \mathrm{mg}-\mathrm{N} / \mathrm{L}$ of total nitrogen and $3.4 \mathrm{mg}-\mathrm{P} / \mathrm{L}$ of total phosphorus. In the inoculum, clade II type nos $Z$ was one order of magnitude higher than clade I type (day 0 of Fig. S3).

\section{Media composition}

The synthetic medium contained (per $1 \mathrm{~L}$ of distilled water): $100 \mathrm{mg}$ of $\mathrm{KH}_{2} \mathrm{PO}_{4}, 6.6 \mathrm{mg}$ of $\mathrm{NaCl}, 8.20 \mathrm{mg}$ of $\mathrm{MgSO}_{4} \cdot 7 \mathrm{H}_{2} \mathrm{O}, 13.4 \mathrm{mg}$ of $\mathrm{KCl}$, and $188 \mathrm{mg}$ of $\mathrm{NaHCO}_{3}$, supplemented with $1 \mathrm{~mL}$ of trace element solution. The trace element solution contained (per $1 \mathrm{~L}$ of distilled water): $10 \mathrm{~g}$ of $\mathrm{FeSO}_{4} \cdot 7 \mathrm{H}_{2} \mathrm{O}, 10 \mathrm{~g}$ of $\mathrm{FeCl}_{3} \cdot 7 \mathrm{H}_{2} \mathrm{O}, 2 \mathrm{~g}$ of $\mathrm{ZnSO}_{4} \cdot 7 \mathrm{H}_{2} \mathrm{O}, 4 \mathrm{~g}$ of $\mathrm{CuSO}_{4} \cdot 7 \mathrm{H}_{2} \mathrm{O}, 0.5 \mathrm{~g}$ of $\mathrm{NaMoO}_{4} \cdot 2 \mathrm{H}_{2} \mathrm{O}, 0.1 \mathrm{~g}$ of $\mathrm{MnCl}_{2} \cdot 4 \mathrm{H}_{2} \mathrm{O}, 0.1 \mathrm{~g}$ of $\mathrm{H}_{3} \mathrm{BO}_{4}, 0.3 \mathrm{~g}$ of $\mathrm{Na}_{2} \mathrm{SeO}_{3}$, and $10 \mathrm{~g}$ of citric acid ${ }^{36}$. In addition, the medium was supplemented with organic carbon and nitrogen sources: a mixture of $\mathrm{CH}_{3} \mathrm{COONa}(170 \mathrm{mg} / \mathrm{L})$ and $\mathrm{NH}_{4} \mathrm{Cl}(22.8 \mathrm{mg})$ for $\mathrm{N}_{2} \mathrm{OFR} 1$; a mixture of bactopeptone $(48.8 \mathrm{mg} / \mathrm{L})$, beef extract $(64.4 \mathrm{mg} / \mathrm{L})$, dextrin $(21.3 \mathrm{mg} / \mathrm{L})$ and yeast extract $(62.0$ $\mathrm{mg} / \mathrm{L}$ ) for $\mathrm{N}_{2} \mathrm{OFR} 2$; and the same mixture as for $\mathrm{N}_{2} \mathrm{OFR} 2$ plus $\mathrm{KNO}_{3}(253 \mathrm{mg} / \mathrm{L})$ for $\mathrm{NO}_{3} \mathrm{FR}$. All media were sterilized by autoclaving and purged for 20 min with $\mathrm{N}_{2}$ gas before use. $\mathrm{CO}_{2}$ stripping during $\mathrm{N}_{2}$ gas purge was minimal $(<2 \%)$.

\section{Chemical analyses}

Samples for water quality analyses were centrifuged at 9,900 $\times \mathrm{g}$ for $10 \mathrm{~min}$, and afterward, the supernatant was filtered using a $0.45 \mu \mathrm{m}$ membrane filter (A045A025A, Advantec, Tokyo, Japan). $\mathrm{NO}_{3}{ }^{-}, \mathrm{NO}_{2}{ }^{-}$and $\mathrm{NH}_{4}{ }^{+}$were analyzed using ion chromatography systems ICS1000 and ICS90 (Dionex, Boston, MA). Dissolved organic carbon (DOC) and dissolved total nitrogen (DTN) were analyzed by a TOC analyzer, installing a total nitrogen measurement unit (TOCV, Shimadzu, Kyoto, Japan). pH was measured using a portable meter (D-53, HORIBA, Kyoto, Japan) equipped with a pH sensor (9625-10D, HORIBA, Kyoto, Japan). Average pH values in 
effluent of $\mathrm{N}_{2} \mathrm{OFR} 1, \mathrm{~N}_{2} \mathrm{OFR} 2$, and $\mathrm{NO}_{3}$ FR were $8.01( \pm 0.40), 7.45( \pm 0.42)$, and $8.46( \pm 0.41)$, respectively. $\mathrm{N}_{2} \mathrm{O}$ concentration in supply gas was determined by a GC-ECD (GC-14B, Shimadzu, Kyoto, Japan).

\section{Biofilm sampling and DNA extraction}

Biofilm samples, developed on the hollow fiber membranes of $\mathrm{N}_{2} \mathrm{OFR} 1$ and $\mathrm{N}_{2} \mathrm{OFR} 2$ (Fig. S2), were sampled through a dedicated port (P3 port in Fig. 1) by inserting a needle. A large portion of biofilm suspension $(2 \mathrm{~mL})$ was removed by suction. The samples were stored at $-20^{\circ} \mathrm{C}$ until DNA extraction. In case of $\mathrm{NO}_{3} \mathrm{FR}$, a $10 \times 10 \mathrm{~mm}$ piece of non-woven sheet was cut and taken, followed by dislodging the biomass with a sterile brush for the collection. DNA was extracted using a FastDNA Spin kit (MP Bio., CA) according to the manufacturer's instructions, followed by measurement using Nanodrop2000c (Thermo Scientific, MA). Extracted DNA was stored at $-20^{\circ} \mathrm{C}$ until analysis.

\section{Real-time qPCR analysis}

Gene abundance for $16 \mathrm{~S}$ rRNA, $\mathrm{N}_{2} \mathrm{O}$ reduction (i.e., clades I and II nosZ) and canonical heterotrophic $\mathrm{NO}_{2}^{-}$reduction (i.e., nirS and nirK) were quantified by real-time qPCR with reported primer sets (Table S1) using a CFX96 Real-Time PCR Detection System (BioRad Laboratories, CA). PCR conditions for the amplification of genes of 16S rRNA, nirS, nirK, clade I nosZ, and clade II nosZ are modified from earlier protocols and described in SI 16,17,3739.

\section{Microbial community analysis}

Amplicons of 16S rRNA gene were generated using the universal primers $515 \mathrm{f}-806 \mathrm{r}{ }^{40}$ and sequenced on a MiSeq DNA sequencer (Illumina, CA) in paired-end sequencing mode. The PhiX, low-quality $(\mathrm{Q}<30)$, and chimeric sequences were removed (Mothur ver. 1.31.2) ${ }^{41}$ and 
the paired-end sequences were assembled as reported previously ${ }^{42}$. Operational taxonomic units (OTUs) were defined based on a 97\% sequence similarity cut-off, and the alpha and beta diversities of libraries were calculated with QIIME (version 1.7.0) ${ }^{43}$. A PCoA plot was generated from weighted UniFrac analysis of libraries after equalizing the sequence number (n $=22,580)$. Sequences have been deposited in DDBJ under BioProject accession number PRJDB4563 (Table S2).

\section{Isolation from the reactor enrichments}

Isolation medium was identical to the enrichment medium, solidified by addition of $2 \mathrm{w} / \mathrm{v} \%$ agar powder (Wako, Saitama, Japan). Besides, diluted-nutrient broth medium and bromothymol blue medium, described elsewhere ${ }^{44,45}$, were used for isolation from the inoculated activated sludge. The enrichment culture from each reactor was sampled (Fig. 1) and serially diluted in phosphate buffered saline after dispersion (PBS, $\mathrm{pH}$ 7.5). The diluted suspensions were spread on respective isolation media, followed by 10 -day incubation in a $5 \% \mathrm{~N}_{2} \mathrm{O}, 20 \% \mathrm{CO}_{2}$, and $75 \%$ $\mathrm{N}_{2}$ atmosphere in an anaerobic chamber (AJ-1, Sanshin, Kanagawa, Japan). Visible colonies were transferred in individual wells of a 96-well plate, followed by re-incubation for 2 weeks in the same condition and liquid media devoid of oxygen. Growth in individual wells was monitored by absorbance of $600 \mathrm{~nm}$ (Infinite F50, Tecan, Switzerland), and wells with positive growth were retained for DNA extraction and sequencing ${ }^{46-47}$ with detailed protocols found in SI. The 16S rRNA gene sequences of representative isolates were deposited in the DDBJ/Genbank/EBI nucleotide sequence database under accession numbers LC097197 to LC097214.

\section{Biokinetic parameter estimation based on $\mathrm{N}_{2} \mathrm{O}$ respirometry}


$\mathrm{N}_{2} \mathrm{O}$ reduction activities of the isolates were characterized via a respirometric system using $\mathrm{N}_{2} \mathrm{O}$ and $\mathrm{O}_{2}$ amperometric microsensors (Unisense, Aarhus, Denmark). The set-up of the system, which monitors $\mathrm{N}_{2} \mathrm{O}$ respiration based on depletion of dissolved $\mathrm{N}_{2} \mathrm{O}$, was reported earlier ${ }^{48}$. Azospira sp. strains I09, I13 and Dechloromonas sp. strain I20, acquired from the $\mathrm{N}_{2} \mathrm{OFRs}$, and Alicycliphilus denitrificans strain $\mathrm{I} 51$ isolated from the $\mathrm{NO}_{3} \mathrm{FR}$, were examined for $\mathrm{N}_{2} \mathrm{O}$ respiration kinetics. The preparation of pre-growth and harvesting is described in SI. Because $\mathrm{N}_{2} \mathrm{O}$-reducing activities of Azospira sp. strains I09 and $\mathrm{I} 13$ decreased by $70-86 \%$ by washing with $0.05 \times$ PBS and centrifugation as previously observed ${ }^{48}$, cell suspensions after pre-growth on enrichment media were neither washed nor centrifuged. Instead, the suspensions were diluted with the media excluding the carbon source and transferred to a double port chamber (volume: $3.06 \mathrm{~mL}$ ) equipped with $\mathrm{O}_{2}$ and $\mathrm{N}_{2} \mathrm{O}$ microsensors (OX-MR and $\mathrm{N} 2 \mathrm{O}-\mathrm{MR}$, response time $<45 \mathrm{sec}$ ). To initiate the respiration test, $10 \mu \mathrm{L}$ of a highly concentrated $\mathrm{N}_{2} \mathrm{O}$ solution $\left(27.05 \mathrm{mM}\right.$ at $20^{\circ} \mathrm{C}$ ) was injected into the chamber yielding initial dissolved $\mathrm{N}_{2} \mathrm{O}$ concentrations between 100-140 $\mu \mathrm{M}$. After 5 min for intensive mixing of $\mathrm{N}_{2} \mathrm{O}$, organic carbon was spiked. In case of Azospira sp. strains I09, I13, and Dechloromonas sp. strain I20, $20 \mu \mathrm{L}$ of $100 \mathrm{mM}$ sodium acetate was added at an initial concentration of $650 \mu \mathrm{M}$ (in stoichiometric excess compared to $\mathrm{N}_{2} \mathrm{O}$ ). In case of Alicycliphilus denitrificans strain $\mathrm{I} 51,25 \mu \mathrm{L}$ of autoclaved broth medium $(2,050 \mathrm{mg}-\mathrm{C} / \mathrm{L})$, consisting of $2.38 \mathrm{~g} / \mathrm{L}$ of bacto-peptone and $3.04 \mathrm{~g} / \mathrm{L}$ of yeast extract, was added. $\mathrm{O}_{2}$ and $\mathrm{N}_{2} \mathrm{O}$ concentrations were continuously recorded at $1 \mathrm{~Hz} \cdot \mathrm{N}_{2} \mathrm{O}$ concentration profiles were subject to the Smooth 2D-data function of Sigma Plot 13.0 (Systat Software, San Jose, CA) to remove high-frequency noise ${ }^{49}$. The $\mathrm{N}_{2} \mathrm{O}$ profiles were used to estimate instantaneous $\mathrm{N}_{2} \mathrm{O}$ reduction rates, $v_{\mathrm{t}}$, and corresponding $\mathrm{N}_{2} \mathrm{O}$ concentrations, $C_{t}$. These $\left(v_{\mathrm{t}}, C_{\mathrm{t}}\right)$ profiles were fit, using least squared error minimization, with the Michaelis-Menten equation 
to estimate maximum $\mathrm{N}_{2} \mathrm{O}$ reduction rate $v_{\max }$, and $\mathrm{N}_{2} \mathrm{O}$ half-saturation coefficient $K_{\mathrm{m}, \mathrm{N} 2 \mathrm{O}}$. In parallel, the rate of abiotic $\mathrm{N}_{2} \mathrm{O}$ loss as the background $\left(v_{\mathrm{b}}: 4.48 \mu \mathrm{M} / \mathrm{h}\right)$ was measured without bacterial cells and subtracted from $v_{\max }$. This subtraction allowed to estimate the maximum

$\mathrm{N}_{2} \mathrm{O}$ reduction rate $v_{\max }$ under anoxic conditions. After $\mathrm{N}_{2} \mathrm{O}$ respirometry, the cell number of the bacterial suspension was determined by microscopy (The details provided in SI and in previous work ${ }^{50}$ ). Cell-specific $\mathrm{N}_{2} \mathrm{O}$ reduction rates, $V_{\max }$, were calculated by dividing $v_{\max }$ by

211 the estimated cell numbers. nm (OD600) using an online monitoring system (OD Monitor C\&T, Taitec, Aichi, Japan), and

214 fitting to equations [1] and [2]:

$$
\frac{d X}{d t}=\mu X
$$

$$
\ln X=\mu t+\ln X_{0}
$$

, where $t$ is time [h], and $X_{0}$ is OD600 at $t=0$. The preparation of isolate cell suspensions and the media composition are described in SI.

\section{Results}

\section{Changes in chemical parameters during the operation of enrichment reactors}

During Phase 1, average dissolved organic carbon removal efficiencies in $\mathrm{N}_{2} \mathrm{OFR} 1, \mathrm{~N}_{2} \mathrm{OFR} 2$ and $\mathrm{NO}_{3} \mathrm{FR}$ were $76 \%, 66 \%$ and $78 \%$, respectively, and during Phase 2 , they improved to $92 \%$, $88 \%$ and $84 \%$, respectively (Details, see Table S3). Neither $\mathrm{NO}_{2}^{-}$nor $\mathrm{NO}_{3}^{-}$was detected in either $\mathrm{N}_{2}$ OFRs during the experimental period (Table S3). The supplied $\mathrm{N}_{2} \mathrm{O}$ and intruding $\mathrm{O}_{2}$ contributed $98 \%$ and $2 \%$, respectively, of the terminal electron acceptors in Phase 1 of the 
The nos $Z$ to $16 \mathrm{~S}$ rRNA relative gene abundance in the three reactors was monitored by realtime quantitative PCR (Fig. 2). The clade II type nos $Z$ was at higher abundance in the $\mathrm{N}_{2} \mathrm{OFRs}$ than in the $\mathrm{NO}_{3} \mathrm{FR}$, whereas the clade I type nos $Z$ was at higher abundance in the $\mathrm{NO}_{3} \mathrm{FR}$ than in the $\mathrm{N}_{2} \mathrm{OFRs}$. In both $\mathrm{N}_{2} \mathrm{OFR} 1$ and $\mathrm{N}_{2} \mathrm{OFR} 2$, clade II type nos $Z$ significantly increased in abundance from ca. $10^{4}$ to ca. $10^{5}$ copies/ng-DNA around day $70-110$ and subsequently decreased (Fig. S4A, B). On the other hand, in the $\mathrm{NO}_{3} \mathrm{FR}$, the relative abundance of clade I type nos $Z$ increased and afterward remained stable (Fig. 2C and S4C). The quantification of the nos $Z$ clade II type should be considered semi-quantitative in view of the well-known low PCR amplification efficiency associated with these primers (amplification efficiency: $75.8 \%$ here $v s .75 \%{ }^{17}$ and $70 \%{ }^{25}$ ).

The microbial community compositions were compared among the three enrichment cultures on the basis of 16S rRNA gene amplicon libraries (Fig. 3A-C). The rapid changes in microbial community compositions were (Fig. 3A-C) likely caused by the high diversity and evenness of the inoculum (Table S2). Proteobacteria and Bacteroidetes dominated all enrichment cultures (Fig. S5A). With acetate (in $\mathrm{N}_{2} \mathrm{OFR} 1$ ), the $\mathrm{N}_{2} \mathrm{O}$-reducing enrichments were predominantly comprised of Betaproteobacteria from $13.2 \%$ on day 0 to $63.5 \%$ on day 79 and steady afterward (Fig. 3A). With the peptone-based mixed substrate (in $\mathrm{N}_{2} \mathrm{OFR} 2$ ), the enrichments were dominated by Betaproteobacteria, Gemmatimonadetes, Sphingobacteriia, Bacteroidia, and Clostridia (Fig. 3B). The relative abundances of Firmicutes abruptly increased to $36.4 \%$ on day 12 whereas that of Bacteroidetes reached a maximum of $40.9 \%$ on day 190 . 
in $\mathrm{N}_{2} \mathrm{O}$-supplying rates (i.e., from day 71) (Fig. 3B). In the $\mathrm{NO}_{3} \mathrm{FR}$, Gammaproteobacteria became dominant with relative abundance as high as $55.5 \%$ on day 79 (Fig. 3C). At the order level, Rhodocyclales dominated the enrichment in $\mathrm{N}_{2} \mathrm{OFR} 1$; and were also dominant though less abundant in $\mathrm{N}_{2}$ OFR2 (Fig. S5B). Throughout the operation, an OTU phylogenetically close to Pseudomonas stutzeri, known as a fast-growing clade I type $\mathrm{N}_{2} \mathrm{O}$-reducing bacterium, was detected at a highest relative abundance of $2.9 \%$ on day 12 in $\mathrm{N}_{2} \mathrm{OFR} 1$ but thereafter decreased below $1 \%$ abundance.

OTUs with relative abundances above $10 \%$ at any time of observation are summarized in Fig. 3D-F. The analysis identified 7 dominant OTUs for each enrichment. In $\mathrm{N}_{2} \mathrm{OFR} 1$, OTUs of the genera Azospira, Dechloromonas and Azonexus (family Rhodocyclaceae, class Betaproteobacteria) together comprised more than $50 \%$ of the entire microbial community. The Rhodocyclaceae family was also predominant in $\mathrm{N}_{2} \mathrm{OFR} 2$. One specific OTU 8208 (Dechloromonas sp.) was enriched in both $\mathrm{N}_{2}$ OFRs, whereas most of the other OTUs were unique to individual $\mathrm{N}_{2} \mathrm{OFR}$. The predominant OTUs in the $\mathrm{NO}_{3} \mathrm{FR}$ were phylogenetically distinct from those in $\mathrm{N}_{2}$ OFRs: OTU 12912 (Pseudoxanthomonas sp.) was the most dominant member with relative abundance above $38.3 \%$, whereas the abundances of OTU12912 in the $\mathrm{N}_{2}$ OFRs were below $0.6 \%$. The taxonomic information of predominant OTUs (relative abundance $>1 \%$ ) was summarized as a heatmap image (Fig. S6).

PCoA plots indicate that the microbial communities in the three reactors dramatically changed during the first 12 days (Fig. 4). Until the end of the operation, a distinctive microbial community was established in each reactor, as the convergence of the microbial communities was observed (Fig. 4 and Table S2). The alpha diversity was lower in $\mathrm{N}_{2} \mathrm{OFR} 1$ than $\mathrm{N}_{2} \mathrm{OFR} 2$ potentially due to the proliferation of non-denitrifying fermentative bacteria with the peptone- 
based medium.

\section{Isolation of $\mathrm{N}_{2} \mathrm{O}$-reducing bacteria from the three reactors and activated sludge}

In total, 219 isolates were obtained from the inoculum and the enrichments from the $\mathrm{N}_{2} \mathrm{OFRs}$ and $\mathrm{NO}_{3} \mathrm{FR}$ on days 35 and 191 based on colony growth in a $5 \% \mathrm{~N}_{2} \mathrm{O}, 20 \% \mathrm{CO}_{2}, 75 \% \mathrm{~N}_{2}$ atmosphere. All isolates were classified in 12 OTUs (at 97\% sequence similarity of $16 \mathrm{~S}$ rRNA genes (Table S4)). Hereafter, the isolates are termed ISO_OTU with a number to distinguish the OTUs.

ISO_OTU 03, closely related to Azospira suillum PS (NR074103) (i.e. also called Dechlorosoma suillum PS), was the dominant isolate from $\mathrm{N}_{2} \mathrm{OFR} 1$ (108/108 isolates) and $\mathrm{N}_{2} \mathrm{OFR} 2$ (5/44 isolates). ISO_OTU 07, related to Dechloromonas sp. strain JM (AF323491), was the most frequent isolate from $\mathrm{N}_{2}$ OFR2 (19/44 isolates). The phylogeny of these isolates (termed ISO_OTU) is compared with the 16S rRNA from the enrichments (termed ENRICH_OTU) and shown in Fig. 5. Based on 16S rRNA gene sequence similarity, the sequence of ISO_OTU 03 is identical (100\% sequence similarity) to ENRICH_OTU 10027, the dominant OTU in $\mathrm{N}_{2}$ OFR1. Likewise, ISO_OTU 07 and ENRICH_OTU 8208, which became predominant in both $\mathrm{N}_{2}$ OFRs, have $98.4 \%$ similarity. These two ISO_OTUs were not isolated from the inoculum nor from the $\mathrm{NO}_{3}{ }^{-}$enrichment culture (Fig. 5) and can, therefore, be considered unique to the $\mathrm{N}_{2} \mathrm{O}$ enrichment. Both ISO_OTUs have a clade II type nos $Z$ confirmed by end-point PCR and the nos $Z$ sequences affiliated with the Rhodocyclaceae (Fig. S7). Besides, these ISO_OTUs harbored a nirS gene and displayed $\mathrm{NO}_{2}^{-}$reduction activity, as confirmed by end-point PCR and physiological testing, respectively (details found in Table S4). Hence, the two isolates ISO_OTU03 and ISO_OTU07 appear to be canonical denitrifying types.

Isolates from $\mathrm{N}_{2} \mathrm{OFR} 2$, which were not retrieved from $\mathrm{N}_{2} \mathrm{OFR} 1$, included ISO_OTUs 01, 
04, 08, 09, and 10 phylogenetically identical to Aeromonas hydrophila (NC_008570), Alycycliphilus denitrificans (KM210250), Acidovorax temperans (NZ_JXYQ00000000), Achromobacter sp. (EU727196), and Pleomorphomonas koreensis strain NBRC 100803 (NZ_AULH00000000), respectively. Their closely related ENRICH_OTU exhibited relatively low abundances $\left(0.005-7.5 \%\right.$ of the total) in $\mathrm{N}_{2} \mathrm{OFR} 2$. End-point PCR confirmed that ISO_OTUs 01, 04, and 08 belong to the nos $Z$ clade I lineage (Table S4). However, ISO_OTUs 09 and 10 could not be classified in either nos $Z$ clade. Their physiological traits could not be further investigated because of our inability to maintain them in cultivation. From the $\mathrm{NO}_{3} \mathrm{FR}$, ISO_OTUs $02,04,08$, and 11 are phylogenetically identical to Stenotrophomonas sp. (KC252893), Alicycliphilus denitrificans, Acidovorax temperans, and Acidovorax sp. (GU184188), respectively. From the inoculum (WWTP activated sludge), five isolates, termed ISO_OTUs 00, 01, 05, 06, and 08, were obtained. ISO_OTUs 00, 05, and 06 were phylogenetically identical to Ralstonia pickettii (NR102967), Pseudomonas nitroreducens (NZ_BDAI00000000), and Neisseriales bacterium (AB769224), respectively. Except ISO_OTU 02 and ISO_OTU10, isolates from the inoculum and $\mathrm{NO}_{3} \mathrm{FR}$ (51/66 isolates) carried the clade I type nos $Z$, and none of them carried the clade II type nos $Z$.

\section{$\mathrm{N}_{2} \mathrm{O}$ reduction activities of the isolated strains}

As representatives of isolates carrying the clade II type nos $Z$, we examined isolates Azospira sp. strains I09 and I13 (ISO_OTU 03) and Dechloromonas sp. strain I20 (ISO_OTU 07) for

$316 \mathrm{~N}_{2} \mathrm{O}$ reduction activity. An isolate of Alicycliphilus denitrificans strain I51 (ISO_OTU 04), 317 repeatedly isolated from $\mathrm{NO}_{3} \mathrm{FR}$ (Fig. 5), was selected as a representative carrying the clade I 318 type nosZ. The isolate Stenotrophomonas sp. I54 (ISO_OTU 02) was likewise selected as 319 another candidate from $\mathrm{NO}_{3} \mathrm{FR}$. End-point PCR using the currently available primer sets for 
nosZ (Table S4), however, suggests that Stenotrophomonas sp. I54 does not carry a currently

known nosZ gene. Spiking $\mathrm{NO}_{2}^{-}$to a vial with Stenotrophomonas sp. I54 cell suspension accumulated $\mathrm{N}_{2} \mathrm{O}$ but no further reduction proceeded (data not shown). Hence, this isolate was subsequently excluded from the $\mathrm{N}_{2} \mathrm{O}$ reduction activity test.

The $\mathrm{N}_{2} \mathrm{O}$ reduction activities of the four isolates (Azospira sp. strains I09 and I13, Dechloromonas sp. strain I20 and Alicycliphilus denitrificans strain I51) were significantly inhibited in the presence of $\mathrm{O}_{2}$, but $\mathrm{N}_{2} \mathrm{O}$ reduction commenced immediately upon $\mathrm{O}_{2}$ depletion

(Fig. S8 for Azospira sp. strain I09). The cell-specific $\mathrm{N}_{2} \mathrm{O}$ reduction rates ( $\left.V_{\max }\right)$ of Azospira sp. strains I09 and I13, and Dechloromonas sp. strain I20 were $4.23 \pm 2.29 \times 10^{-3}, 1.79 \pm 0.24$ $\times 10^{-2}$, and $1.80 \pm 0.46 \times 10^{-2} \mathrm{pmol} / \mathrm{h} / \mathrm{cell}$, respectively (Fig. S9 and Table 2). The respective $K_{\mathrm{m}, \mathrm{N} 2 \mathrm{O}}$ values were $1.55 \pm 0.61,2.10 \pm 0.26$, and $2.04 \pm 0.13 \mu \mathrm{M}$ (Table 2). The clade I type $n_{n}$ isolate, Alicycliphilus denitrificans strain I51, had a lower $V_{\max }\left(3.78 \pm 2.29 \times 10^{-3}\right.$ pmol/h/cell) than Azospira sp. strain I13 and Dechloromonas sp. strain I20, and it had a higher $K_{\mathrm{m}, \mathrm{N} 2 \mathrm{O}}(8.98 \pm 1.83 \mu \mathrm{M})$ than the clade II type nos $Z$ isolates (Table 2). The $a_{0}$ values of the isolates Dechloromonas sp. strain I20 (ISO_OTU 07) and Azospira sp. strain I13 (ISO_OTU03) were 21.7- and 20.4-fold higher, respectively, compared with that of isolate Alicycliphilus denitrificans strain I51 affiliated with the clade I type nosZ (Table 2). The specific growth rates $\left(\mu\left[\mathrm{h}^{-1}\right]\right)$ of the four isolates obtained in the enrichment reactors differed with electron acceptor and donor (Table 2). The clade II type nos $Z$ isolates displayed higher growth rates with $\mathrm{N}_{2} \mathrm{O}$ than nitrite whereas the clade I type nos $Z$ isolate showed the opposite pattern (Table 2).

Discussion 
We demonstrate, for the first time, that $\mathrm{N}_{2} \mathrm{OFRs}$ with gas-permeable membranes allow for the selective enrichment of $\mathrm{N}_{2} \mathrm{O}$-reducing bacteria especially those carrying the clade II type nos $\mathrm{Z}$ gene (Fig. 2A-B). In light of the long-term operation of $\mathrm{N}_{2} \mathrm{OFRs}$ and $\mathrm{NO}_{3} \mathrm{FR}$, niche differentiation between the two distinct nos $Z$ clade types in the biofilm reactors appears governed by the type of electron acceptor, i.e., $\mathrm{N}_{2} \mathrm{O} v$ s. nitrate, rather than that of electron donor, i.e., acetate vs. peptone-based substrate (Fig. 2A-B). Previous research has suggested that oxygen level ${ }^{51}$, affinity for $\mathrm{N}_{2} \mathrm{O}^{23}$, dilution rate ${ }^{25}$ and $\mathrm{pH}^{22,52}$ are determining factors of clade I and II type nosZ. Our results indicate the significance of electron acceptor on the predominance of the clade II type nos $Z$. Our successful enrichment of clade II type nos $Z$ bacteria through $\mathrm{N}_{2} \mathrm{O}$ supply contrasts with the enrichment of nos $Z$ clade I type bacteria in a chemostat continuous culture with $\mathrm{N}_{2} \mathrm{O}$ as a sole electron acceptor ${ }^{25}$. Another study suggests the effect of chemostat dilution rate on selection of clade I versus clade II type $\operatorname{nos} Z \mathrm{~N}_{2} \mathrm{O}$ reducers, with lower dilution rates favoring clade II type nos $Z$ types ${ }^{33}$. In biofilm-based systems, hydraulic dilution rates do not control selection of predominant bacteria. Instead, extremely long solid retention times and multiple environmental niches are created in biofilms. Such heterogeneity of environmental conditions enriches not only the limited types of bacteria optimally adapted to one situation (as in a chemostat) but various types of bacteria including high-affinity $\mathrm{N}_{2} \mathrm{O}$ reducers (Fig. 2 and Fig. 3).

Supply of nitrate $\left(\mathrm{NO}_{3} \mathrm{FR}\right)$ enriched clade I type nos $\mathrm{Z}$ bacteria rather than the clade II type bacteria (Fig. 2C), indicating the dominant role of electron acceptor type on the enrichment of the nos $Z$ clade in biofilm-based systems. The concomitant increases in $n o s Z$ clade I and $n i r S / K$ gene abundances from day 0 to 35 (Fig. S4C) suggests the enrichment of canonical denitrifying bacteria. 
Despite the enrichment of clade II type nos $Z$, the conditions imposed in $\mathrm{N}_{2} \mathrm{OFRs}$ did not

favor the growth of non-denitrifying $\mathrm{N}_{2} \mathrm{O}$ reducers, consistent with observations in chemostat enrichments ${ }^{25,33}$. Yoon et al. (2016) ${ }^{24}$ report that the non-denitrifying $\mathrm{N}_{2} \mathrm{O}$-reducer,

Anaeromyxobacter dehalogenans strain 2CP-C, has one order of magnitude lower $\mu_{\max }$ value than canonical denitrifying $\mathrm{N}_{2} \mathrm{O}$ reducers, Pseudomonas stutzeri strain DCP-Ps1 and Dechloromonas aromatica strain RCB. Conthe et al. (2018) ${ }^{25}$ underpin that $\mathrm{N}_{2} \mathrm{O}$-limitation does not provide a selective advantage for non-denitrifying $\mathrm{N}_{2} \mathrm{O}$ reducers. In a recent metagenomic study, Lawson et al. (2017) ${ }^{53}$ detected a clade II type non-denitrifying $\mathrm{N}_{2} \mathrm{O}$ reducers of the phylum Chlorobi and suggested it thrives off extracellular proteins, excreted from anammox bacteria in a reactor devoid of external organic carbon supply. The selective growth on extracellular compounds indicates the importance of selecting an electron donor to enrich clade II type non-denitrifying $\mathrm{N}_{2} \mathrm{O}$ reducers. Although electron donor choice may not be the sole determinant to enrich non-denitrifying $\mathrm{N}_{2} \mathrm{O}$ reducers ${ }^{15}$, our observations suggest that canonical denitrifying $\mathrm{N}_{2} \mathrm{O}$ reducers thrive when carbon substrate are abundant. The condition between clade II type non-denitrifying and canonical denitrifying $\mathrm{N}_{2} \mathrm{O}$ reducers as a function of type and supply of carbon source is needed.

\section{The effect of electron donor and acceptor on predominant bacterial taxa}

We show that in a biofilm-based reactor, $\mathrm{N}_{2} \mathrm{OFR}$, fed with $\mathrm{N}_{2} \mathrm{O}$ as sole electron acceptor, enriched the genus Dechloromonas, canonical denitrifying bacteria possessing the clade II type $n o s Z^{17,18}$. Despite our hypothesis that $\mathrm{N}_{2}$ OFRs allow enrichment of phylogenetically diverse $\mathrm{N}_{2} \mathrm{O}$ reducers, only Betaproteobacteria were enriched in $\mathrm{N}_{2}$ OFRs. The genus Dechloromonas has recently been documented as capable of reducing $\mathrm{N}_{2} \mathrm{O}$ 23,33 but is better known for its ability for anaerobic degradation of (per)chlorate ${ }^{54-56}$ and benzene ${ }^{57}$. In stark contrast, the clade I type 
nosZ canonical denitrifiers, e.g., Pseudomonas stutzeri, were not detected in either $\mathrm{N}_{2} \mathrm{OFR}$ enrichment, even though this bacterium, with high maximum specific growth rate and affinity constant for $\mathrm{N}_{2} \mathrm{O}{ }^{23}$, was detected as a predominant type in a chemostat enrichment fed with $\mathrm{N}_{2} \mathrm{O}$ and acetate ${ }^{25}$. The difference regarding the presence of $P$. stutzeri between this and previous studies corroborates that a membrane bioreactor, fed with $\mathrm{N}_{2} \mathrm{O}$ and acetate, provides niches, just like chemostat reactors, for high-affinity (high $a_{0}$ ) $\mathrm{N}_{2} \mathrm{O}$ reducers, possessing a lower maximum specific growth rate and affinity constant for $\mathrm{N}_{2} \mathrm{O}$ than $P$. stutzeri (Table 2). A detailed explanation of why $r$-strategist $\mathrm{N}_{2} \mathrm{O}$-reducers like $P$. stutzeri are not enriched in biofilm awaits further study.

The peptone-based mixed substrate supplied to $\mathrm{N}_{2} \mathrm{OFR} 2$ resulted in the enrichment of a more diverse microbial community including potential $\mathrm{N}_{2} \mathrm{O}$-reducing bacteria (Table S2). $\mathrm{N}_{2} \mathrm{O}$-reducing bacteria affiliated with phyla Bacteroidetes, Firmicutes and Gemmatimonadetes were only enriched in $\mathrm{N}_{2} \mathrm{OFR} 2$ (Fig. S5A and S6). Species of Bacteroidetes and Gemmatimonadetes, e.g., Gemmatimonas aurantiaca, recently identified as $\mathrm{N}_{2} \mathrm{O}$-reducing bacteria ${ }^{58}$, are known to degrade proteins ${ }^{59-61}$. The phylum Chlorobi, often found in anammox systems ${ }^{53,62}$, was probably not enriched due to the lack of an essential ingredient in the medium 53. In addition, some OTUs in $\mathrm{N}_{2} \mathrm{OFR} 2$ (e.g., Clostridiaceae and Comamonadaceae ${ }^{63,64}$ ) that are neither denitrifying nor $\mathrm{N}_{2} \mathrm{O}$-reducing, are potentially fermentative. These fermentative taxa may contribute to the increase on alpha diversity in $\mathrm{N}_{2} \mathrm{OFR} 2$ (Table S2). For selective enrichment of a broader set of non-denitrifying $\mathrm{N}_{2} \mathrm{O}$ reducers, more complex growth media may need to be provided.

\section{Biokinetics of isolates suggests promising $\mathrm{N}_{2} \mathrm{O}$-reducers}

Azospira sp. and Dechloromonas sp. isolates were only obtained from $\mathrm{N}_{2} \mathrm{OFRs}$ and not from 
$412 \mathrm{NO}_{3} \mathrm{FR}$ nor the inoculum, underscoring the significance of the enrichment procedure to attain 413 clade II type nos $Z$ canonical denitrifiers. Members of the Rhodocyclaceae, including the genera

414 Dechloromonas and Azospira, have often been detected or isolated from activated sludge as 415 major heterotrophic denitrifiers ${ }^{65-68}$ and also as an autotrophic denitrifiers oxidizing $\mathrm{H}_{2}$ or $\mathrm{Fe}^{2+}$ $416 \quad 69$. In this family, the genera Dechloromonas and Azospira have the documented metabolic 417 property of $\mathrm{N}_{2} \mathrm{O}$ reduction ${ }^{23,48}$. This study extends our knowledge on the microbial species that 418 can perform $\mathrm{N}_{2} \mathrm{O}$ reduction in WWTPs ${ }^{15}$.

Higher substrate affinity for $\mathrm{N}_{2} \mathrm{O}\left(a_{0}\right)$ governs the selection of predominant $\mathrm{N}_{2} \mathrm{O}$-reducing bacteria, supported by the higher $a_{0}$ values of the isolates Dechloromonas sp. strain I20 (ISO_OTU 07) and Azospira sp. strain I13 (ISO_OTU03) (Table 2). The high $a_{0}$ values are caused by the relatively low $K_{\mathrm{m}, \mathrm{N} 2 \mathrm{O}}$ values, which are slightly higher but comparable with the values of known clade II type $\mathrm{N}_{2} \mathrm{O}$-reducing bacteria, such as Flavobacterium sp. $(0.5 \mu \mathrm{M})^{24}$ and Anaeromyxobacter dehalogenans $(1.34 \mu \mathrm{M})^{23}$ (Table 2). In stark contrast, the $K_{\mathrm{m}, \mathrm{N} 2 \mathrm{O}}$ of Alicycliphilus denitrificans strain I51 (ISO_OTU 02), an isolate of the clade I type nosZ lineage, is much higher $(8.98 \pm 1.83 \mu \mathrm{M})$ (Table 2). Moreover, the clade II type nos $Z$ isolates favored $\mathrm{N}_{2} \mathrm{O}$ over nitrite as an electron acceptor, in contrast to the clade I type nos $Z$ isolate. Our biokinetic analysis supports the hypothesis that clade II type nos $Z$ bacteria may function as $\mathrm{N}_{2} \mathrm{O}$ sinks more effectively than clade I type nos $Z$ bacteria ${ }^{23}$. phylogenetically identical to ENRICH_OTU9398 (7\% at 12 day), enriched in $\mathrm{NO}_{3} \mathrm{FR}$ and analysis with the BLAST genome information ${ }^{70}$ revealed the absence of a nos $Z$ motif in the 
does not necessarily lead to success in enriching $\mathrm{N}_{2} \mathrm{O}$-reducing bacteria, but may also enrich partial denitrifiers.

The isolates affiliated with both $\operatorname{nos} Z$ clade I and clade II span a limited phylogenetic range, suggesting bias due to the cultivation method. Different cultivation methods might be required to access more phylogenetically diverse isolates.

\section{The implication for active $\mathrm{N}_{2} \mathrm{O}$-reducing bacteria}

The successful enrichment of high-affinity $\mathrm{N}_{2} \mathrm{O}$-reducing bacteria in this study could pave the way for a novel $\mathrm{N}_{2} \mathrm{O}$ mitigation strategy in WWTPs ${ }^{4}$. As a means to alleviate $\mathrm{N}_{2} \mathrm{O}$ emissions from WWTPs, bioreactor conditions have been optimized that would enrich $\mathrm{N}_{2} \mathrm{O}$-reducing bacteria and passage of exhaust gas through an $\mathrm{N}_{2} \mathrm{O}$-reducing biofilter has been explored ${ }^{26,71}$. In addition, $\mathrm{N}_{2} \mathrm{O}$ mitigation based on bioaugmentation by $\mathrm{N}_{2} \mathrm{O}$-reducing strains has been proposed ${ }^{52,72,73}$. The previous augmentation with $\mathrm{N}_{2} \mathrm{O}$-reducing bacteria was not successful in the long-term ${ }^{74}$, likely due to the discrepancy between the actual reactor conditions and optimal conditions for bacterial activity. Given that dissolved $\mathrm{N}_{2} \mathrm{O}$ concentration in activated sludge systems ranges from 0.02 to $10 \mu \mathrm{M}$ (Fig. S10), the high $K_{\mathrm{m}, \mathrm{N} 2 \mathrm{O}}$ value, e.g., $35.5 \pm 9.3 \mu \mathrm{M}$ for P. stutzeri DCP-Ps1 ${ }^{23}$, would not suffice for in situ $\mathrm{N}_{2} \mathrm{O}$ reduction despite the high $V_{\max }$. The lower $K_{\mathrm{m}, \mathrm{N} 2 \mathrm{O}}$ found in the clade II type nosZ bacteria Dechloromonas sp. and Azospira sp. (Table 2) presents a clear advantage over the clade I type nos $Z$ bacteria especially in the $\mathrm{N}_{2} \mathrm{O}$ concentration range observed in wastewater treatment bioreactors (Fig. S10). Non-denitrifying $\mathrm{N}_{2} \mathrm{O}$-reducing bacteria, e.g., Anaeromyxobacter sp., isolated from rice paddies ${ }^{75}$, probably have too low specific growth rates and prefer to thrive in oligotrophic environments. Yet, canonical denitrifiers with high $\mathrm{N}_{2} \mathrm{O}$ affinities, i.e., Dechloromonas sp. and Azospira sp., as identified here, may operate as effective $\mathrm{N}_{2} \mathrm{O}$ sinks under conditions of high-nitrogen turnover conditions. 
Together, the clade II type nosZ bacteria possessing canonical denitrifying genes (nirS or nirK) are plausible candidates for $\mathrm{N}_{2} \mathrm{O}$ mitigation in engineered bioreactor systems.

By supplying $\mathrm{N}_{2} \mathrm{O}$ via a gas-permeable membrane in continuous-flow reactors, we can selectively enrich $\mathrm{N}_{2} \mathrm{O}$-reducing bacteria possessing the clade II type $\operatorname{nos} Z$. In the $\mathrm{N}_{2} \mathrm{OFRs}$, the Dechloromonas and Azospira genera of the Rhodocyclaceae family became dominant. From the enrichment, we successfully isolated bacterial types of these genera with a high degree of success (132 out of 152 isolates). Representative isolates of both genera, exhibited higher $\mathrm{N}_{2} \mathrm{O}$ affinities than the typical clade I nos $Z$ canonical denitrifying bacteria. At the dissolved $\mathrm{N}_{2} \mathrm{O}$ concentration range observed in WWTPs, the biokinetic traits of these representative strains show excellent potential to serve as an $\mathrm{N}_{2} \mathrm{O}$ sink. This study, therefore, underscores the success of enrichment by a membrane-based $\mathrm{N}_{2} \mathrm{O}$-supplied biofilm reactor permitting the isolation of clade II type $\operatorname{nos} Z \mathrm{~N}_{2} \mathrm{O}$-reducing bacteria.

\section{Conflict of Interest}

The authors declare that there are no conflicts of interest in this manuscript.

\section{Acknowledgments}

We acknowledge Dr. Tomo Aoyagi, Dr. Kang Song, Ms. Kanako Mori and Ms. Fumi Shimura for technical support on reactor operation and 16S rRNA gene amplicon sequencing. This work was supported by the Grant-in-Aid for Challenging Exploratory Research (26630420, 16K12616), the Grand-in-Aid for Scientific Research (17H01893), the Grand-in-Aid for JSPS Fellows (16J08601), the Open Partnership Joint Research Projects (Japan-Denmark) from Japan Society for the Promotion of Science (JSPS), and the Danish Free Research Council 
(N2OMAN grant nr. DFF-1335-00100)

482

483

\section{Supporting Information}

484

485

486

487

488

489

490

491

492

493

494

495

496

497

498

499

500

501

502

503

The additional information of materials and methods, Fig.S1-S10 and Table S1-S4 are supplied as Supporting Information.

\section{References}

(1) Ravishankara, A. R.; Daniel, J. S.; Portmann, R. W. Nitrous Oxide ( $\left.\mathrm{N}_{2} \mathrm{O}\right)$ : The Dominant Ozone-Depleting Substance Emitted in the 21st Century. Science (80-. ). 2009, 326 (5949), 123-125. https://doi.org/10.1126/science.1176985.

(2) Zumft, W. G.; Kroneck, P. M. H. Respiratory Transformation of Nitrous Oxide $\left(\mathrm{N}_{2} \mathrm{O}\right)$ to Dinitrogen by Bacteria and Archaea. Adv. Microb. Physiol. 2006, 52 (06), 107-227. https://doi.org/10.1016/S0065-2911(06)52003-X.

(3) IPCC. Climate Change 2014 Synthesis Report Summary Chapter for Policymakers. Ipcc 2014, 31. https://doi.org/10.1017/CBO9781107415324.

(4) Law, Y.; Ye, L.; Pan, Y.; Yuan, Z. Nitrous Oxide Emissions from Wastewater Treatment Processes. Philos. Trans. R. Soc. B Biol. Sci. 2012, 367 (1593), 1265-1277. https://doi.org/10.1098/rstb.2011.0317.

(5) Kampschreur, M. J.; Temmink, H.; Kleerebezem, R.; Jetten, M. S. M.; van Loosdrecht, M. C. M. Nitrous Oxide Emission during Wastewater Treatment. Water Res. 2009, 43 (17), 4093-4103. https://doi.org/10.1016/j.watres.2009.03.001.

(6) Ali, M.; Rathnayake, R. M. L. D.; Zhang, L.; Ishii, S.; Kindaichi, T.; Satoh, H.; Toyoda, S.; Yoshida, N.; Okabe, S. Source Identification of Nitrous Oxide Emission 
Pathways from a Single-Stage Nitritation-Anammox Granular Reactor. Water Res.

2016, 102, 147-157. https://doi.org/10.1016/j.watres.2016.06.034.

(7) Harris, E.; Joss, A.; Emmenegger, L.; Kipf, M.; Wolf, B.; Mohn, J.; Wunderlin, P.

Isotopic Evidence for Nitrous Oxide Production Pathways in a Partial Nitritation-

(9) Wunderlin, P.; Lehmann, M. F.; Siegrist, H.; Tuzson, B.; Joss, A.; Emmenegger, L.; Mohn, J. Isotope Signatures of $\mathrm{N}_{2} \mathrm{O}$ in a Mixed Microbial Population System: Constraints on $\mathrm{N}_{2} \mathrm{O}$ Producing Pathways in Wastewater Treatment. Environ. Sci. Technol. 2013, 47 (3), 1339-1348. https://doi.org/10.1021/es303174x.

(10) Ahn, J. H.; Kim, S.; Park, H.; Rahm, B.; Pagilla, K.; Chandran, K. N $2 \mathrm{O}$ Emissions from Activated Sludge Processes, 2008-2009: Results of a National Monitoring Survey in the United States. Environ. Sci. Technol. 2010, 44 (12), 4505-4511. https://doi.org/10.1021/es903845y.

(11) Domingo-Félez, C.; Mutlu, A. G.; Jensen, M. M.; Smets, B. F. Aeration Strategies to Mitigate Nitrous Oxide Emissions from Single-Stage Nitritation/Anammox Reactors. Environ. Sci. Technol. 2014, 48 (15), 8679-8687. https://doi.org/10.1021/es501819n.

(12) Rodriguez-Caballero, A.; Ribera, A.; Balcázar, J. L.; Pijuan, M. Nitritation versus Full Nitrification of Ammonium-Rich Wastewater: Comparison in Terms of Nitrous and 
Nitric Oxides Emissions. Bioresour. Technol. 2013, 139, 195-202.

https://doi.org/10.1016/j.biortech.2013.04.021.

(13) Song, K.; Suenaga, T.; Hamamoto, A.; Satou, K.; Riya, S.; Hosomi, M.; Terada, A. Abundance, Transcription Levels and Phylogeny of Bacteria Capable of Nitrous Oxide Reduction in a Municipal Wastewater Treatment Plant. J. Biosci. Bioeng. 2014, 118 (3), 289-297. https://doi.org/10.1016/j.jbiosc.2014.02.028.

(14) Noda, N.; Kaneko, N.; Milkami, M.; Kimochi, Y.; Tsuneda, S.; Hirata, A.; Mizuochi, M.; Inamori, Y. Effects of SRT and DO on $\mathrm{N}_{2} \mathrm{O}$ Reductase Activity in an Anoxic-Oxic Activated Sludge System. Water Sci. Technol. 2003, 48 (11-12), 363-370.

(15) Hallin, S.; Philippot, L.; Löffler, F. E.; Sanford, R. A.; Jones, C. M. Genomics and Ecology of Novel $\mathrm{N}_{2} \mathrm{O}-\mathrm{Reducing}$ Microorganisms. Trends Microbiol. 2018, 26 (1), 4355. https://doi.org/https://doi.org/10.1016/j.tim.2017.07.003.

(16) Henry, S.; Bru, D.; Stres, B.; Hallet, S.; Philippot, L. Quantitative Detection of the NosZ Gene, Encoding Nitrous Oxide Reductase, and Comparison of the Abundances of 16S RRNA, NarG, NirK, and NosZ Genes in Soils. Appl. Environ. Microbiol. 2006, 72 (8), 5181-5189. https://doi.org/10.1128/AEM.00231-06.

(17) Jones, C. M.; Graf, D. R. H.; Bru, D.; Philippot, L.; Hallin, S. The Unaccounted yet Abundant Nitrous Oxide-Reducing Microbial Community: A Potential Nitrous Oxide Sink. ISME J. 2013, 7 (2), 417-426. https://doi.org/10.1038/ismej.2012.125.

(18) Sanford, R. A.; Wagner, D. D.; Wu, Q.; Chee-Sanford, J. C.; Thomas, S. H.; CruzGarcía, C.; Rodríguez, G.; Massol-Deyá, A.; Krishnani, K. K.; Ritalahti, K. M.; Nissen, S.; Konstantinidis, K. T.; Loffler, F. E. Unexpected Nondenitrifier Nitrous Oxide Reductase Gene Diversity and Abundance in Soils. Proc. Natl. Acad. Sci. U. S. A. 
2012, 109 (48), 19709-19714. https://doi.org/10.1073/pnas.1211238109.

551

552

(19) Graf, D. R. H.; Jones, C. M.; Hallin, S. Intergenomic Comparisons Highlight Modularity of the Denitrification Pathway and Underpin the Importance of Community Structure for $\mathrm{N}_{2} \mathrm{O}$ Emissions. PLoS One 2014, 9 (12), 1-20. https://doi.org/10.1371/journal.pone.0114118.

(20) Orellana, L. H.; Rodriguez-R, L. M.; Higgins, S.; Chee-Sanford, J. C.; Sanford, R. A.; Ritalahti, K. M.; Löffler, F. E.; Konstantinidis, K. T. Detecting Nitrous Oxide Reductase (NosZ) Genes in Soil Metagenomes: Method Development and Implications for the Nitrogen Cycle. MBio 2014, 5 (3), e01193-14. https://doi.org/10.1128/mBio.01193-14.

(21) Domeignoz-Horta, L. A.; Spor, A.; Bru, D.; Breuil, M. C.; Bizouard, F.; Léonard, J.; Philippot, L. The Diversity of the $\mathrm{N}_{2} \mathrm{O}$ Reducers Matters for the $\mathrm{N}_{2} \mathrm{O}: \mathrm{N}_{2}$ Denitrification End-Product Ratio across an Annual and a Perennial Cropping System. Front. Microbiol. 2015, 6 (SEP). https://doi.org/10.3389/fmicb.2015.00971.

(22) Jones, C. M.; Spor, A.; Brennan, F. P.; Breuil, M. C.; Bru, D.; Lemanceau, P.; Griffiths, B.; Hallin, S.; Philippot, L. Recently Identified Microbial Guild Mediates Soil $\mathrm{N}_{2} \mathrm{O}$ Sink Capacity. Nat. Clim. Chang. 2014, 4 (9), 801-805. https://doi.org/Doi 10.1038/Nclimate2301.

(23) Yoon, S.; Nissen, S.; Park, D.; Sanford, R. A.; Löffler, F. E. Nitrous Oxide Reduction Kinetics Distinguish Bacteria Harboring Clade I versus Clade II NosZ. 2016, No. April. https://doi.org/10.1128/AEM.00409-16.

(24) Betlach, M. R.; Tiedje, J. M. Kinetic Explanation for Accumulation of Nitrite, Nitric Oxide, and Nitrous Oxide during Bacterial Denitrification. Appl. Environ. Microbiol. 
1981, 42 (6), 1074-1084. https://doi.org/Article.

(25) Conthe, M.; Wittorf, L.; Kuenen, J. G.; Kleerebezem, R.; van Loosdrecht, M. C. M.; Hallin, S. Life on $\mathrm{N}_{2} \mathrm{O}$ : Deciphering the Ecophysiology of $\mathrm{N}_{2} \mathrm{O}$ Respiring Bacterial Communities in a Continuous Culture. ISME J. 2018, No. February, 1-12. https://doi.org/10.1038/s41396-018-0063-7.

(26) Yoon, H.; Song, M. J.; Yoon, S. Design and Feasibility Analysis of a Self-Sustaining Biofiltration System for Removal of Low Concentration $\mathrm{N}_{2} \mathrm{O}$ Emitted from Wastewater Treatment Plants. Environ. Sci. Technol. 2017, 51 (18), 10736-10745. https://doi.org/10.1021/acs.est.7b02750.

(27) Yoon, H.; Song, M. J.; Kim, D. D.; Sabba, F.; Yoon, S. A Serial Biofiltration System for Effective Removal of Low-Concentration Nitrous Oxide in Oxic Gas Streams: Mathematical Modeling of Reactor Performance and Experimental Validation. Environ. Sci. Technol. 2019, 53 (4), 2063-2074. https://doi.org/10.1021/acs.est.8b05924.

(28) Lee, K.-C.; Rittmann, B. E. A Novel Hollow-Fibre Membrane Biofilm Reactor for Autohydrogenotrophic Denitrification of Drinking Water. Water Sci. Technol. 2000, 41 (4-5), 219 LP - 226.

(29) Nerenberg, R. The Membrane-Biofilm Reactor (MBfR) as a Counter-Diffusional Biofilm Process. Curr. Opin. Biotechnol. 2016, 38, 131-136. https://doi.org/10.1016/j.copbio.2016.01.015.

(30) Terada, A.; Yamamoto, T.; Igarashi, R.; Tsuneda, S.; Hirata, A. Feasibility of a Membrane-Aerated Biofilm Reactor to Achieve Controllable Nitrification. Biochem. Eng. J. 2006, 28 (2), 123-130. https://doi.org/10.1016/j.bej.2005.10.001. 
(31) Cole, A. C.; Semmens, M. J.; LaPara, T. M. Stratification of Activity and Bacterial Community Structure in Biofilms Grown on Membranes Transferring Oxygen. Appl. Environ. Microbiol. 2004, 70 (4), 1982-1989. https://doi.org/10.1128/aem.70.4.19821989.2004.

(32) Wilderer, P. A.; Brautigam, J.; Sekoulov, I. Application of Gas Permeable Membranes for Auxiliary Oxygenation of Sequencing Batch Reactors. Conserv. Recycl. 1985, 8, 181-192. https://doi.org/10.1016/0361-3658(85)90035-9.

(33) Conthe, M.; Kuenen, J. G.; Kleerebezem, R.; van Loosdrecht, M. C. M. Exploring Microbial $\mathrm{N}_{2} \mathrm{O}$ Reduction: A Continuous Enrichment in Nitrogen Free Medium. Environ. Microbiol. Rep. 2018, 10 (1), 102-107. https://doi.org/10.1111/17582229.12615.

(34) Kinh, C. T.; Suenaga, T.; Hori, T.; Riya, S.; Hosomi, M.; Smets, B. F.; Terada, A. Counter-Diffusion Biofilms Have Lower $\mathrm{N}_{2} \mathrm{O}$ Emissions than Co-Diffusion Biofilms during Simultaneous Nitrification and Denitrification: Insights from Depth-Profile Analysis. Water Res. 2017, 124, 363-371. https://doi.org/10.1016/j.watres.2017.07.058.

(35) Isaka, K.; Sumino, T.; Tsuneda, S. High Nitrogen Removal Performance at Moderately Low Temperature Utilizing Anaerobic Ammonium Oxidation Reactions. J. Biosci. Bioeng. 2007, 103 (5), 486-490. https://doi.org/10.1263/jbb.103.486.

(36) Miyahara, M.; Kim, S. W.; Fushinobu, S.; Takaki, K.; Yamada, T.; Watanabe, A.; Miyauchi, K.; Endo, G.; Wakagi, T.; Shoun, H. Potential of Aerobic Denitrification by Pseudomonas stutzeri TR2 to Reduce Nitrous Oxide Emissions from Wastewater Treatment Plants. Appl. Environ. Microbiol. 2010, 76 (14), 4619-4625. 
https://doi.org/10.1128/AEM.01983-09.

(37) Henry, S.; Baudoin, E.; Lopez-Gutierrez, J. C.; Martin-Laurent, F.; Brauman, A.; Philippot, L. Quantification of Denitrifying Bacteria in Soils by NirK Gene Targeted Real-Time PCR. J. Microbiol. Methods 2004, 59 (3), 327-335. https://doi.org/10.1016/j.mimet.2004.07.002.

(38) Song, K.; Suenaga, T.; Harper, W. F.; Hori, T.; Riya, S.; Hosomi, M.; Terada, A. Effects of Aeration and Internal Recycle Flow on Nitrous Oxide Emissions from a Modified Ludzak-Ettinger Process Fed with Glycerol. Environ. Sci. Pollut. Res. 2015, 22 (24), 19562-19570. https://doi.org/10.1007/s11356-015-5129-8.

(39) Throbäck, I. N.; Enwall, K.; Jarvis, Å.; Hallin, S. Reassessing PCR Primers Targeting NirS, NirK and NosZ Genes for Community Surveys of Denitrifying Bacteria with DGGE. FEMS Microbiol. Ecol. 2004, 49 (3), 401-417. https://doi.org/10.1016/j.femsec.2004.04.011.

(40) Caporaso, J. G.; Lauber, C. L.; Walters, W. A.; Berg-Lyons, D.; Lozupone, C. A.; Turnbaugh, P. J.; Fierer, N.; Knight, R. Global Patterns of 16S rRNA Diversity at a Depth of Millions of Sequences per Sample. Proc. Natl. Acad. Sci. 2011, 108 (Supplement_1), 4516-4522.https://doi.org/10.1073/pnas.1000080107.

(41) Schloss, P. D.; Westcott, S. L.; Ryabin, T.; Hall, J. R.; Hartmann, M.; Hollister, E. B.; Lesniewski, R. A.; Oakley, B. B.; Parks, D. H.; Robinson, C. J.; Sahl, J.W.; Stres, B.; Thallinger, G. G.; Van Horn, D. J.; Weber, C.F. Introducing Mothur: Open-Source, Platform-Independent, Community-Supported Software for Describing and Comparing Microbial Communities. Appl. Environ. Microbiol. 2009, 75 (23), 7537-7541. https://doi.org/10.1128/aem.01541-09. 
642

643

644

645

646

647

648

649

650

651

652

653

654

655

656

657

658

659

660

661

662

663

664

(42) Itoh, H.; Aita, M.; Nagayama, A.; Meng, X.-Y.; Kamagata, Y.; Navarro, R.; Hori, T.;

Ohgiya, S.; Kikuchi, Y. Evidence of Environmental and Vertical Transmission of Burkholderia Symbionts in the Oriental Chinch Bug, Cavelerius Saccharivorus (Heteroptera: Blissidae). Appl. Environ. Microbiol. 2014, 80 (19), 5974-5983. https://doi.org/10.1128/aem.01087-14.

(43) Caporaso, J. G.; Kuczynski, J.; Stombaugh, J.; Bittinger, K.; Bushman, F. D.; Costello, E. K.; Fierer, N.; Pena, A. G.; Goodrich, J. K.; Gordon, J. I.; Huttley, G. A.; Kelley, S. T.; Knights, D.; Koenig, J. E.; Ley, R. E.; Lozupone, C. A.; McDonald, D.; Muegge, B. D.; Pirrung, M.; Reeder, J.; Sevinsky, J. R.; Tumbaugh, P. J.; Walters, W. A.;

Widmann, J.; Yatsunenko, T.; Zaneveld, J.; Knight, R. QIIME Allows Analysis of High-Throughput Community Sequencing Data. Nat. Methods 2010, 7 (5), 335-336. https://doi.org/10.1038/nmeth.f.303.

(44) Takaya, N.; Catalan-Sakairi, M. A. B.; Sakaguchi, Y.; Kato, I.; Zhou, Z.; Shoun, H. Aerobic Denitrifying Bacteria That Produce Low Levels of Nitrous Oxide. Appl. Environ. Microbiol. 2003, 69 (6), 3152-3157. https://doi.org/10.1128/AEM.69.6.3152.

(45) Hashimoto, T.; Koga, M.; Masaoka, Y. Advantages of a Diluted Nutrient Broth Medium for Isolating $\mathrm{N}_{2}$-Producing Denitrifying Bacteria of $\alpha$-Proteobacteria in Surface and Subsurface Upland Soils. Soil Sci. Plant Nutr. 2009, 55 (5), 647-659. https://doi.org/10.1111/j.1747-0765.2009.00404.x.

(46) Weisburg, W. G.; Barns, S. M.; Pelletier, D. A.; Lane, D. J. 16S Ribosomal DNA Amplification for Phylogenetic Study. J. Bacteriol. 1991, 173 (2), 697-703.

(47) Hori, T.; Aoyagi, T.; Itoh, H.; Narihiro, T.; Oikawa, A.; Suzuki, K.; Ogata, A.; Friedrich, M. W.; Conrad, R.; Kamagata, Y. Isolation of Microorganisms Involved in 
665

666

667

668

669

670

671

672

673

674

675

676

677

678

679

680

681

682

683

684

685

686

687

Reduction of Crystalline Iron(III) Oxides in Natural Environments. Front. Microbiol.

2015, 6 (MAY), 1-16. https://doi.org/10.3389/fmicb.2015.00386.

(48) Suenaga, T.; Riya, S.; Hosomi, M.; Terada, A. Biokinetic Characterization and Activities of $\mathrm{N}_{2} \mathrm{O}$-Reducing Bacteria in Response to Various Oxygen Levels. Front. Microbiol. 2018, 9 (April), 1-10. https://doi.org/10.3389/fmicb.2018.00697.

(49) Martens-Habbena, W.; Berube, P. M.; Urakawa, H.; de la Torre, J. R. J. R.; Stahl, D.

A.; Torre, J.; Stahl, D. A. Ammonia Oxidation Kinetics Determine Niche Separation of Nitrifying Archaea and Bacteria. Nature 2009, 461 (7266), 976-979.

https://doi.org/10.1038/nature08465.

(50) Lunau, M.; Lemke, A.; Walther, K.; Martens-Habbena, W.; Simon, M. An Improved Method for Counting Bacteria from Sediments and Turbid Environments by Epifluorescence Microscopy. Environ. Microbiol. 2005, 7 (7), 961-968. https://doi.org/10.1111/j.1462-2920.2005.00767.x.

(51) Wittorf, L.; Bonilla-Rosso, G.; Jones, C. M.; Bäckman, O.; Hulth, S.; Hallin, S. Habitat Partitioning of Marine Benthic Denitrifier Communities in Response to Oxygen Availability. Environ. Microbiol. Rep. 2016, 8, 486-492. https://doi.org/10.1111/17582229.12393.

(52) Domeignoz-Horta, L. A.; Putz, M.; Spor, A.; Bru, D.; Breuil, M. C.; Hallin, S.; Philippot, L. Non-Denitrifying Nitrous Oxide-Reducing Bacteria - An Effective $\mathrm{N}_{2} \mathrm{O}$ Sink in Soil. Soil Biol. Biochem. 2016, 103, 376-379. https://doi.org/10.1016/j.soilbio.2016.09.010.

(53) Lawson, C. E.; Wu, S.; Bhattacharjee, A. S.; Hamilton, J. J.; McMahon, K. D.; Goel, R.; Noguera, D. R. Metabolic Network Analysis Reveals Microbial Community 
Interactions in Anammox Granules. Nat. Commun. 2017, 8 (May), 1-12. https://doi.org/10.1038/ncomms15416.

(54) Bruce, R. a; Achenbach, L. a; Coates, J. D. Reduction of (per)Chlorate by a Novel Organism Isolated from Paper Mill Waste. Environ. Microbiol. 1999, 1 (4), 319-329. https://doi.org/10.1046/j.1462-2920.1999.00042.x.

(55) Achenbach, L. A.; Michaelidou, U.; Bruce, R. A.; Fryman, J.; Coates, J. D. Dechloromonas agitata gen. nov., sp. nov. and Dechlorosoma suillum Gen. nov., sp. nov., Two Novel Environmentally Dominant (per)Chlorate- Reducing Bacteria and Their Phylogenetic Position Laurie. Int. J. Syst. Evol. Microbiol. 2001, 51 (August), 527-533. https://doi.org/10.1099/00207713-51-2-527.

(56) Sturchio, N. C.; Böhlke, J. K.; Beloso Abelardo D.; Streger, S. H.; Heraty, L. J.; Hatzinger, P. B. Oxygen and Chlorine Isotopic Fractionation during Perchlorate Biodegradation: Laboratory Results and Implications for Forensics and Natural Attenuation Studies. Environ. Sci. Technol. 2007, 41 (8), 2796-2802. https://doi.org/10.1021/es0621849.

(57) Coates, J. D.; Chakraborty, R.; Lack, J. G.; O’Connor, S. M.; Cole, K. a; Bender, K. S.; Achenbach, L. a. Anaerobic Benzene Oxidation Coupled to Nitrate Reduction in Pure Culture by Two Strains of Dechloromonas. Nature 2001, 411 (6841), 1039-1043. https://doi.org/10.1038/35082545.

(58) Park, D.; Kim, H.; Yoon, S. Nitrous Oxide Reduction by an Obligate Aerobic Bacterium Gemmatimonas Aurantiaca Strain T-27. Appl. Environ. Microbiol. 2017, No. April, AEM.00502-17. https://doi.org/10.1128/AEM.00502-17.

(59) van Veen, W. L.; van der Kooij, D.; Geuze, E. C. W. A.; van der Vlies, A. W. 
Investigations on the Sheathed Bacterium Haliscomenobacter hydrossis gen., sp., Isolated from Activated Sludge. Antonie Van Leeuwenhoek 1973, 39 (1), 207-216. https://doi.org/10.1007/BF02578853.

(60) Xia, Y.; Kong, Y.; Thomsen, T. R.; Nielsen, P. H. Identification and Ecophysiological Characterization of Epiphytic Protein-Hydrolyzing Saprospiraceae ("Candidatus Epiflobacter" Spp.) in Activated Sludge. Appl. Environ. Microbiol. 2008, 74 (7), 22292238. https://doi.org/10.1128/AEM.02502-07.

(61) Zhang, H.; Sekiguchi, Y.; Hanada, S.; Hugenholtz, P.; Kim, H.; Kamagata, Y.; Nakamura, K. Gemmatimonas aurantiaca gen. nov., sp. nov., a Gram-Negative, Aerobic, Polyphosphate-Accumulating Micro-Organism, the First Cultured Representative of the New Bacterial Phylum Gemmatimonadetes Phyl. Nov. Int. J. Syst. Evol. Microbiol. 2003, 53 (4), 1155-1163. https://doi.org/10.1099/ijs.0.02520-0.

(62) Speth, D. R.; In'T Zandt, M. H.; Guerrero-Cruz, S.; Dutilh, B. E.; Jetten, M. S. M. Genome-Based Microbial Ecology of Anammox Granules in a Full-Scale Wastewater Treatment System. Nat. Commun. 2016, 7. https://doi.org/10.1038/ncomms11172.

(63) Müller, V. Bacterial Fermentation. Encycl. Life Sci. 2008, No. September. https://doi.org/10.1002/9780470015902.a0001415.pub2.

(64) Willems, A.; De Vos, P. Comamonas. The Prokaryotes 2006, 723-736. https://doi.org/10.1007/0-387-30745-1_31.

(65) Wagner, M.; Loy, A. Bacterial Community Composition and Function in Sewage Treatment Systems. Curr. Opin. Biotechnol. 2002, 13 (3), 218-227. https://doi.org/10.1016/S0958-1669(02)00315-4.

(66) Heylen, K.; Vanparys, B.; Wittebolle, L.; Verstraete, W.; Boon, N.; De Vos, P. 
Cultivation of Denitrifying Bacteria: Optimization of Isolation Conditions and

Diversity Study. Appl. Environ. Microbiol. 2006, 72 (4), 2637-2643.

https://doi.org/10.1128/aem.72.4.2637-2643.2006.

737

738

739

740

741

(67) Osaka, T.; Yoshie, S.; Tsuneda, S.; Hirata, A.; Iwami, N.; Inamori, Y. Identification of Acetate- or Methanol-Assimilating Bacteria under Nitrate-Reducing Conditions by Stable-Isotope Probing. Microb. Ecol. 2006, 52 (2), 253-266.

https://doi.org/10.1007/s00248-006-9071-7.

(68) Morgan-Sagastume, F.; Nielsen, J. L.; Nielsen, P. H. Substrate-Dependent Denitrification of Abundant Probe-Defined Denitrifying Bacteria in Activated Sludge. FEMS Microbiol. Ecol. 2008, 66 (2), 447-461. https://doi.org/10.1111/j.15746941.2008.00571.x.

(69) Di Capua, F.; Pirozzi, F.; Lens, P. N. L.; Esposito, G. Electron Donors for Autotrophic Denitrification. Chem. Eng. J. 2019, 362 (3), 922-937. https://doi.org/10.1016/j.cej.2019.01.069.

(70) Altschul, S. F.; Gish, W.; Miller, W.; Myers, E. W.; Lipman, D. J. Basic Local Alignment Search Tool. J. Mol. Biol. 1990, 215 (3), 403-410. https://doi.org/https://doi.org/10.1016/S0022-2836(05)80360-2.

(71) Frutos, O. D.; Arvelo, I. A.; Pérez, R.; Quijano, G.; Muñoz, R. Continuous Nitrous Oxide Abatement in a Novel Denitrifying Off-Gas Bioscrubber. Appl. Microbiol. Biotechnol. 2015, 99 (8), 3695-3706. https://doi.org/10.1007/s00253-014-6329-8.

(72) Itakura, M.; Uchida, Y.; Akiyama, H.; Hoshino, Y. T.; Shimomura, Y.; Morimoto, S.; Tago, K.; Wang, Y.; Hayakawa, C.; Uetake, Y.; Sánchez, C.; Eda, S. Hayatsu, M.; Minamisawa, K.; Mitigation of Nitrous Oxide Emissions from Soils by 
Bradyrhizobium Japonicum Inoculation. Nat. Clim. Chang. 2013, 3 (3), 208-212. https://doi.org/10.1038/nclimate1734.

759

760

761

762

763

764

765

766

767

768

769

770

771

772

773

774

775

776

777

778

779

(73) Gao, M.; Yang, S.; Wang, M.; Wang, X. H. Nitrous Oxide Emissions from an Aerobic Granular Sludge System Treating Low-Strength Ammonium Wastewater. J. Biosci. Bioeng. 2016, 122 (5), 601-605. https://doi.org/10.1016/j.jbiosc.2016.04.004.

(74) Ikeda-Ohtsubo, W.; Miyahara, M.; Kim, S.-W.; Yamada, T.; Matsuoka, M.; Watanabe, A.; Fushinobu, S.; Wakagi, T.; Shoun, H.; Miyauchi, K.; Endo, G. Bioaugmentation of a Wastewater Bioreactor System with the Nitrous Oxide-Reducing Denitrifier Pseudomonas stutzeri Strain TR2. J. Biosci. Bioeng. 2013, 115 (1), 37-42. https://doi.org/10.1016/j.jbiosc.2012.08.015.

(75) Ishii, S.; Ashida, N.; Otsuka, S.; Senoo, K. Isolation of Oligotrophic Denitrifiers Carrying Previously Uncharacterized Functional Gene Sequences. Appl. Environ. Microbiol. 2011, 77 (1), 338-342. https://doi.org/10.1128/AEM.02189-10.

(76) Betlach, M. R.; Tiedje, J. M. Kinetic Explanation for Accumulation of Nitrite, Nitric Oxide, and Nitrous Oxide during Bacterial Denitrification. Appl. Environ. Microbiol. 1981, 42 (6), 1074-1084. https://doi.org/Article.

(77) Kristjansson, J. K.; Hollocher, T. C. 1st Practical Assay for Soluble Nitrous-Oxide Reductase of Denitrifying Bacteria and a Partial Kinetic Characterization. J. Biol. Chem. 1980, 255 (2), 704-707.

(78) Matsubara T.; Mori, T. Studies on Denitrification. J. Biochem. 1968, 64 (6), 863-871.

(79) St John, R. T.; Hollocher, T. C. Nitrogen 15 Tracer Studies on the Pathway of Denitrification in Pseudomonas aeruginosa. J. Biol. Chem. 1977, 252 (1), 212-218.

(80) Itakura, M.; Tabata, K.; Eda, S.; Mitsui, H.; Murakami, K.; Yasuda, J.; Minamisawa, 
K. Generation of Bradyrhizobium japonicum Mutants with Increased $\mathrm{N}_{2} \mathrm{O}$ Reductase Activity by Selection after Introduction of a Mutated DnaQ Gene. Appl. Environ. Microbiol. 2008, 74 (23), 7258-7264. https://doi.org/10.1128/AEM.01850-08.

(81) Bergaust, L.; van Spanning, R. J. M.; Frostegård, Å.; Bakken, L. R. Expression of Nitrous Oxide Reductase in Paracoccus Denitrificans Is Regulated by Oxygen and https://doi.org/10.1099/mic.0.054148-0.

787 


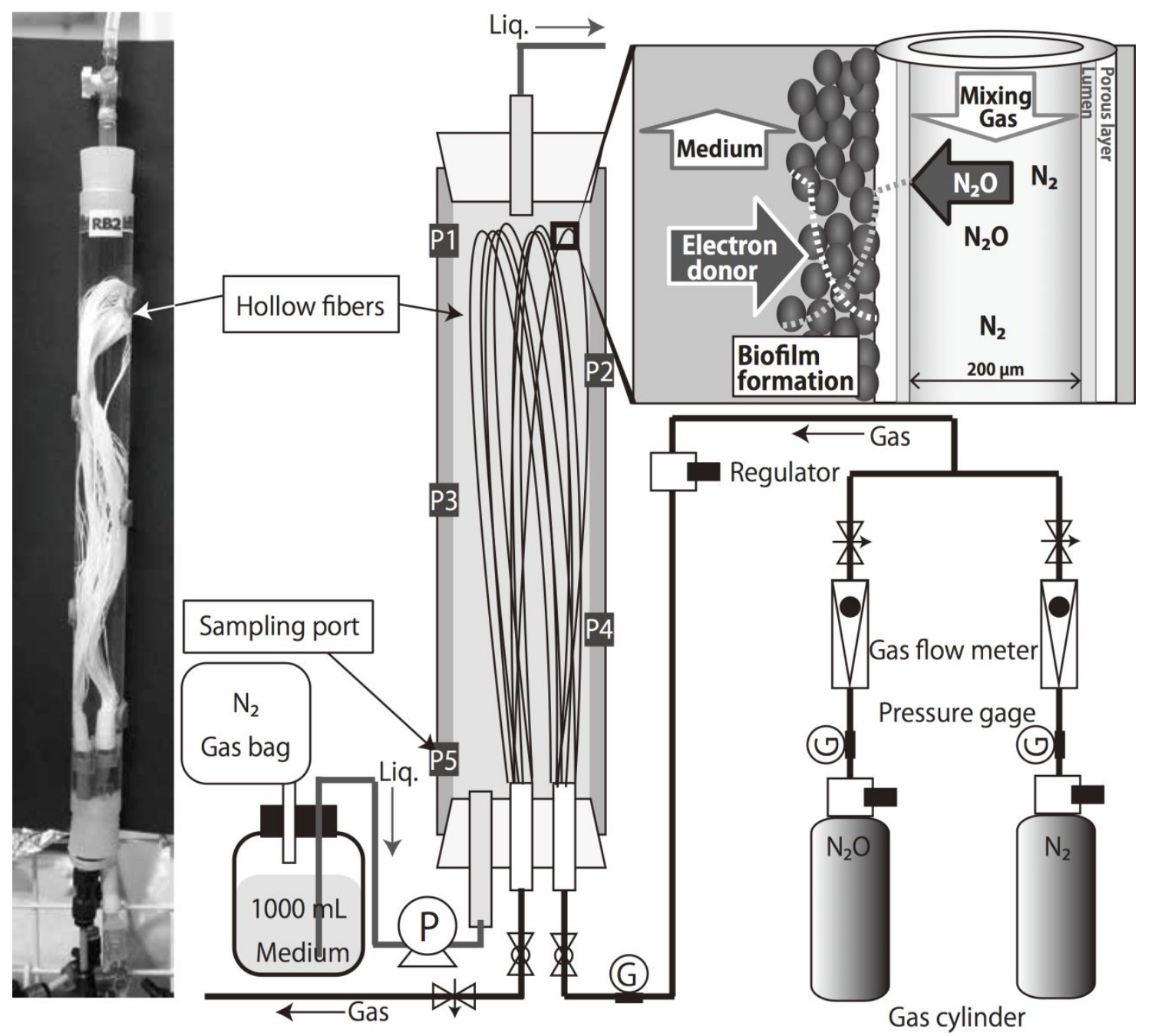

Fig. 1. Schematic diagram of an $\mathrm{N}_{2} \mathrm{O}$-fed reactor 
(a)
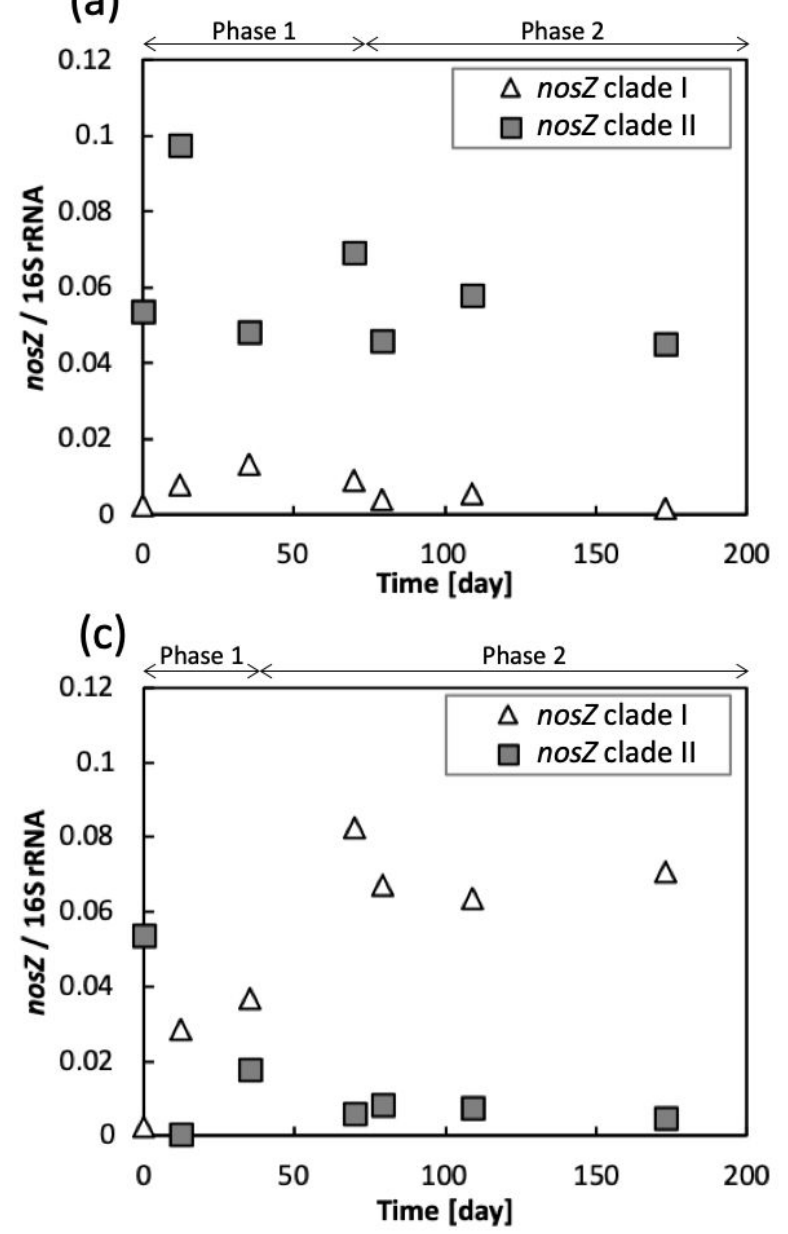

(b)

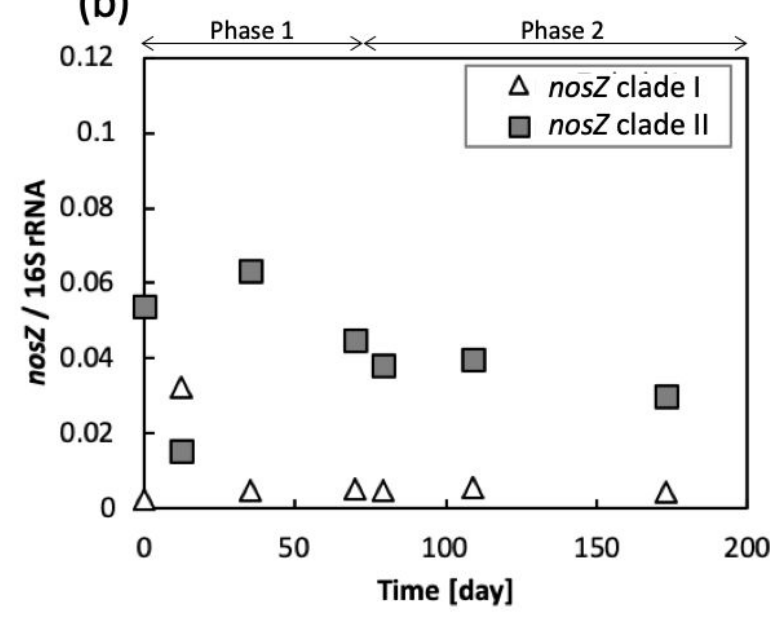

Fig. 2. Dynamics of relative abundances of nos $Z$ clade I type (triangle) and clade II type (square) versus $16 \mathrm{~S}$ rRNA genes in (a) $\mathrm{N}_{2} \mathrm{OFR} 1$, (b) $\mathrm{N}_{2} \mathrm{OFR} 2$ and (c) $\mathrm{NO}_{3} \mathrm{FR}$. The value on day 0 refers to the inoculum. 

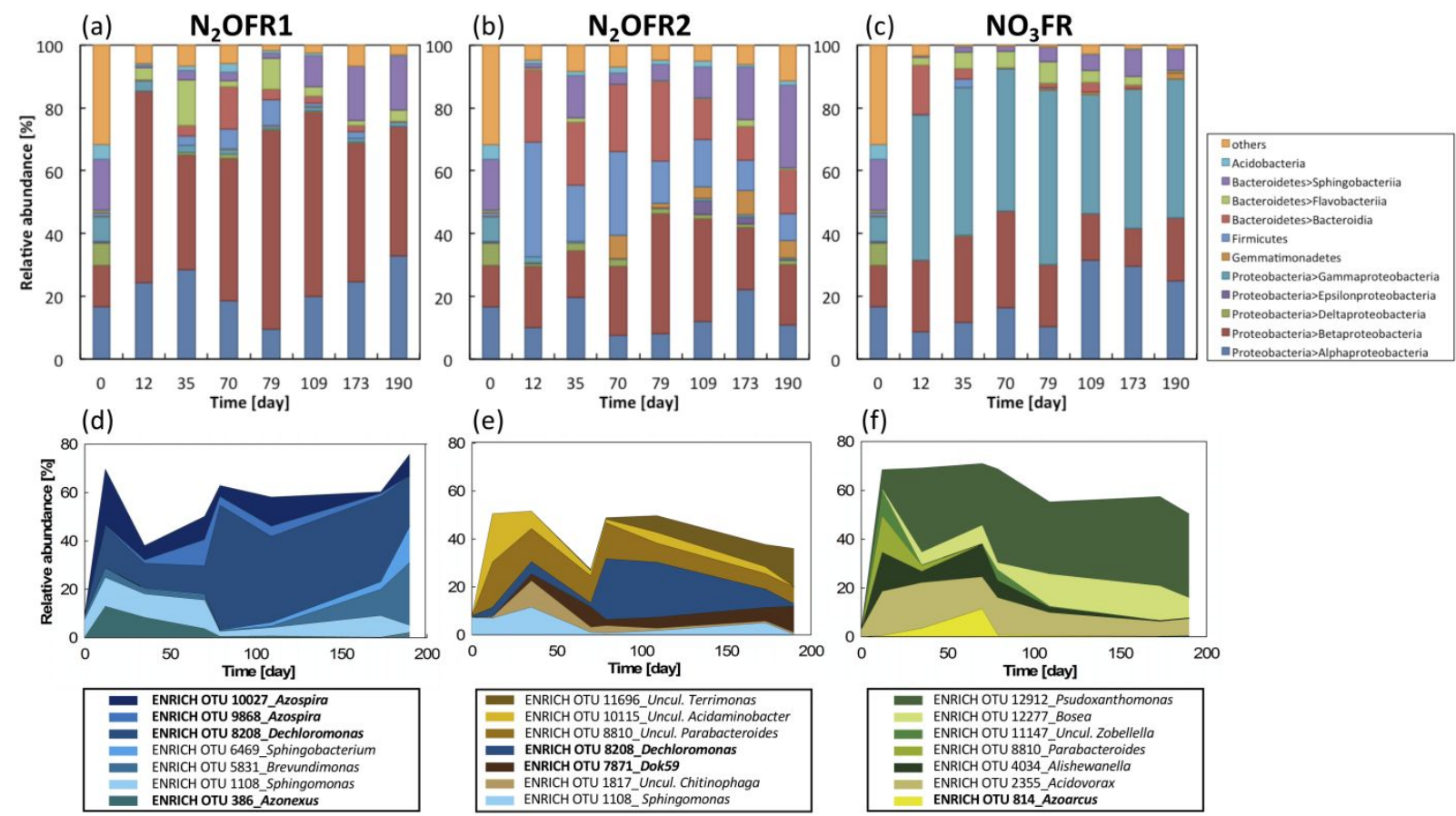

Fig. 3. Structural changes of microbial communities at the class level (Proteobacteria) in (a) $\mathrm{N}_{2} \mathrm{OFR} 1$, (b) $\mathrm{N}_{2} \mathrm{OFR} 2$, and (c) $\mathrm{NO}_{3} \mathrm{FR}$ and at the OTU level in (d) $\mathrm{N}_{2} \mathrm{OFR} 1$, (e) $\mathrm{N}_{2} \mathrm{OFR} 2$, and (f) $\mathrm{NO}_{3} \mathrm{FR}$. OTUs with relative abundances more than $10 \%$ were extracted from the $16 \mathrm{~S}$ rRNA gene amplicon sequencing results as dominant species (in bold OTU belonging to family Rhodocyclaceae). The name of each OTU was chosen after the closest species in BLAST analysis. (g) Principal coordinate analysis (PCoA) plot of amplicon-sequencing data. The statistical analysis was performed by UniFrac analysis of equal numbers of the bacterial sequences $(\mathrm{n}=22,580)$, and the dot size reflects alpha-diversity (Shannon, Table S2). 


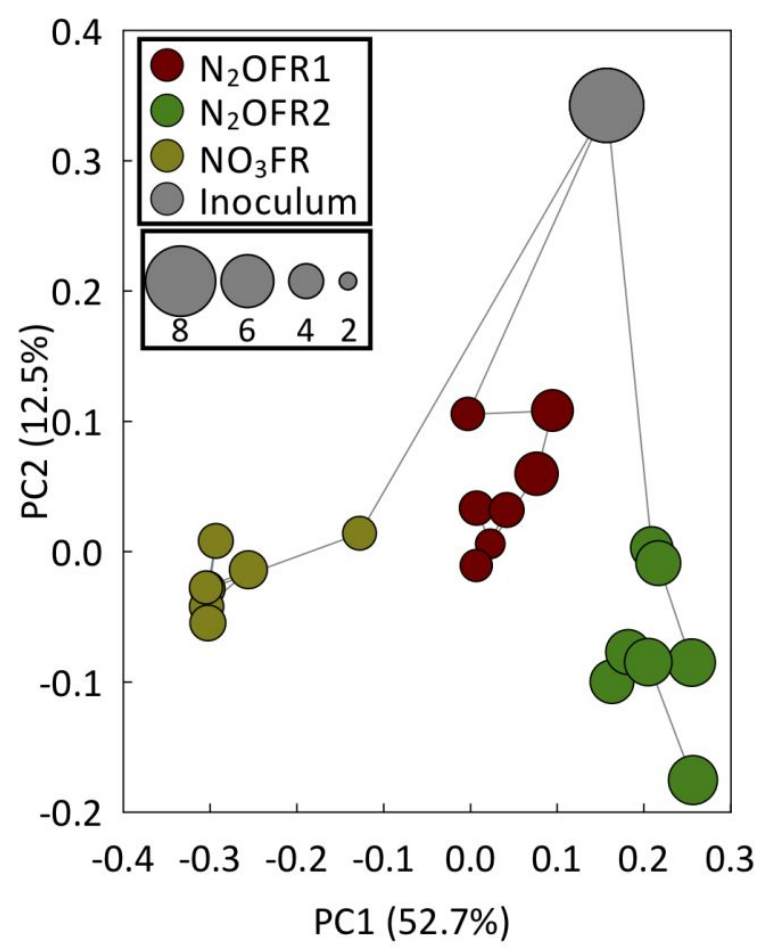

Fig. 4. Variation of principal coordinate analysis (PCoA) plot of deep-sequencing data. The statistical analysis was performed by UniFrac analysis of equal numbers of the bacterial sequences $(n=22,580)$, and the plot size reflects alpha-diversity (Shannon, Table S2). 


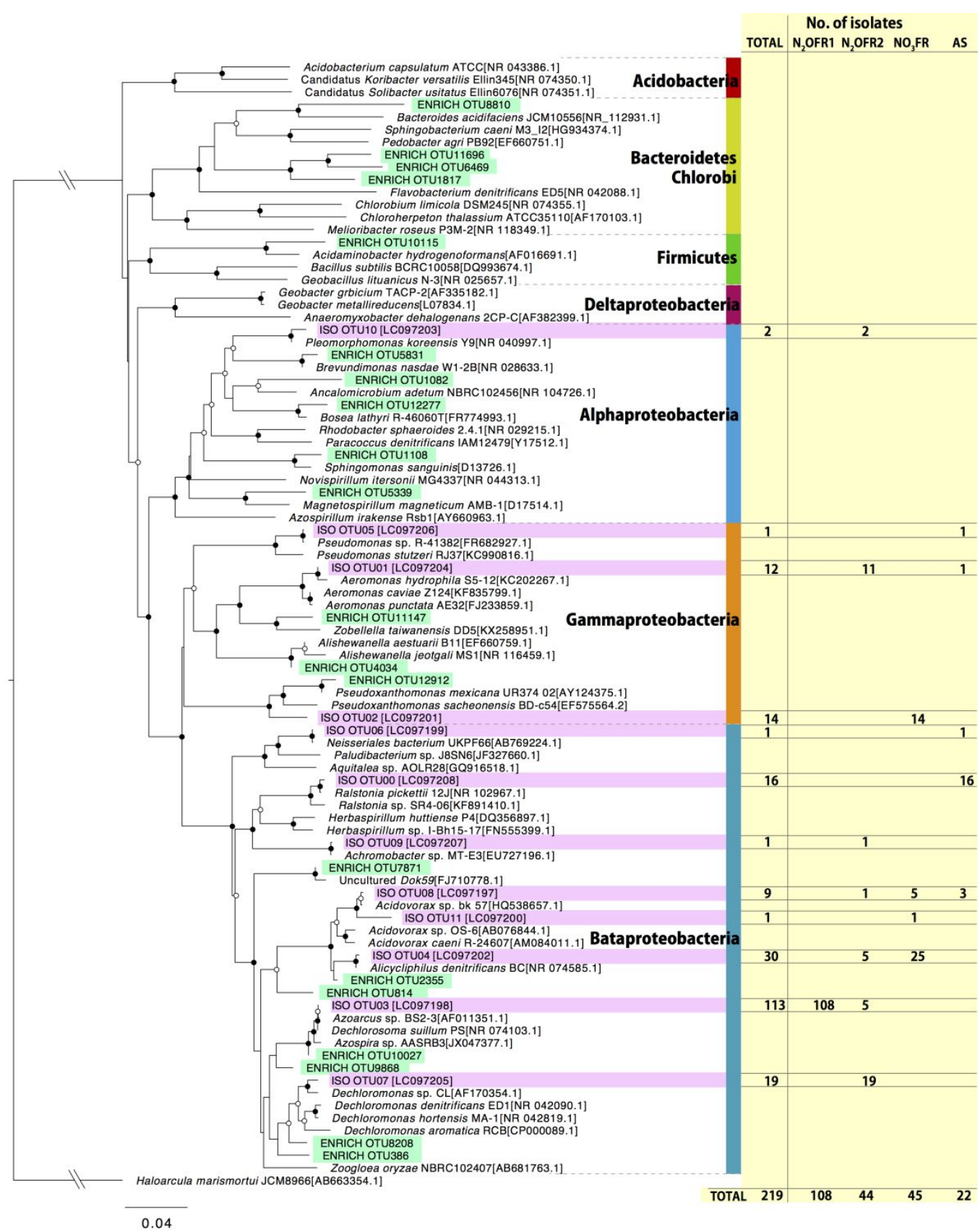

Fig. 5. Phylogenetic tree based on the $16 \mathrm{~S}$ rRNA gene sequences from community DNA in each reactor $($ ENRICH_OTU **) and isolated strains (ISO_OTU **). Scale bar represents nucleotide substitutions per site. Bootstrap values are derived from 1000 replicates, indicated as $>750$ (closed circles) and in the range of 500 to 750 (open circles) at each node. Isolated strains from inoculum activated sludge are in column with label "AS". 
Table 1. Reactor setup and operating conditions

\begin{tabular}{|c|c|c|c|c|c|c|c|}
\hline \multirow[t]{2}{*}{ Reactor } & \multirow{2}{*}{$\begin{array}{c}\text { Electron } \\
\text { donor }\end{array}$} & \multirow{2}{*}{$\begin{array}{c}\text { Electron donor supply }[\mathrm{gC} / \mathrm{L} / \mathrm{day}] \\
\text { (Influent organic carbon concentration } \\
[\mathrm{mgC} / \mathrm{L}]) \\
\end{array}$} & \multirow{2}{*}{$\begin{array}{l}\text { Electron } \\
\text { acceptor }\end{array}$} & \multicolumn{2}{|c|}{$\begin{array}{c}\text { Electron acceptor supply [gN/L/day] } \\
\text { (Influent nitrogen concentration [mgN/L]) }\end{array}$} & \multicolumn{2}{|c|}{ 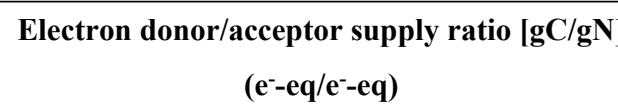 } \\
\hline & & & & Phase 1 * & Phase 2 ** & Phase 1 & Phase 2 \\
\hline $\mathrm{N}_{2} \mathrm{OFR} 1$ & Acetate & $\begin{array}{c}0.184 \\
(53.7 \pm 7.0)\end{array}$ & $\mathrm{N}_{2} \mathrm{O}$ & $\begin{array}{c}0.147 \\
(0.404)^{* * *}\end{array}$ & $\begin{array}{c}2.12 \\
(5.83)^{* * *}\end{array}$ & $\begin{array}{c}1.24 \\
(5.83)\end{array}$ & $\begin{array}{l}0.0865 \\
(0.404)\end{array}$ \\
\hline $\mathrm{N}_{2} \mathrm{OFR} 2$ & $\begin{array}{c}\text { Mixed } \\
\text { substrate }\end{array}$ & $\begin{array}{c}0.248 \\
(72.5 \pm 11.1)\end{array}$ & $\mathrm{N}_{2} \mathrm{O}$ & $\begin{array}{c}0.147 \\
(0.404)^{* * *}\end{array}$ & $\begin{array}{c}2.12 \\
(5.83)^{* * *}\end{array}$ & $\begin{array}{c}1.68 \\
(9.85)\end{array}$ & $\begin{array}{c}0.117 \\
(0.683)\end{array}$ \\
\hline $\mathrm{NO}_{3} \mathrm{FR}$ & $\begin{array}{c}\text { Mixed } \\
\text { substrate }\end{array}$ & $\begin{array}{c}0.229 \\
(66.9 \pm 16.6)\end{array}$ & $\mathrm{NO}_{3}^{-}$ & $\begin{array}{c}0.134 \\
(39.1 \pm 7.2)\end{array}$ & $\begin{array}{c}0.392 \\
(114.5 \pm 8.3)\end{array}$ & $\begin{array}{c}1.71 \\
(2.00)\end{array}$ & $\begin{array}{c}0.584 \\
(0.682)\end{array}$ \\
\hline
\end{tabular}

${ }^{*}: \mathrm{N}_{2}$ OFRs: 0 - 71 day, $\mathrm{NO}_{3}$ FR: 0 - 38 day

${ }^{* *}$ : $\mathrm{N}_{2}$ OFRs: 71 - 191 day, $\mathrm{NO}_{3} \mathrm{FR}: 38$ - 191 day

${ }^{* * *}$ : Estimated maximum equilibrium concentration from $\mathrm{N}_{2} \mathrm{O}$ partial pressure 
Table $2 \mathrm{~N}_{2} \mathrm{O}$ reduction activity of reference and newly isolated strains. $n . d$. represents no growth.

\begin{tabular}{|c|c|c|c|c|c|c|c|c|}
\hline \multirow{2}{*}{ Isolated strains } & \multirow{2}{*}{ nos $Z$ type } & \multirow{2}{*}{$\begin{array}{c}V_{\max } \\
{\left[\times 10^{-3} \mathrm{pmol} / \mathrm{hr} / \mathrm{cell}\right]}\end{array}$} & \multirow{2}{*}{$\begin{array}{c}K_{\mathrm{m}, \mathrm{N} 2 \mathrm{O}} \\
{[\mu \mathrm{M}]}\end{array}$} & \multirow{2}{*}{$\begin{array}{c}a_{0} \\
{\left[\times 10^{-9} \mathrm{~L} / \mathrm{cell} / \mathrm{hr}\right]^{* *}}\end{array}$} & \multicolumn{3}{|c|}{$\mu\left[\mathbf{h}^{-1}\right]$} & \multirow[t]{2}{*}{ Reference } \\
\hline & & & & & $\mathrm{N}_{2} \mathrm{O}$-Acetate & $\mathrm{N}_{2} \mathrm{O}$-Pep.,Yeast ext. & $\mathrm{NO}_{2}^{-+}+$Pep.,Yeast ext. & \\
\hline Dechloromonas sp. I20 (ISO_OTU 07) & clade II & $18.0 \pm 4.6$ & $2.04 \pm 0.13$ & 8.82 & 0.198 & 0.328 & 0.155 & This study \\
\hline Azospira sp. I09 (ISO_OTU 03) & clade II & $4.23 \pm 2.29$ & $1.55 \pm 0.61$ & 2.73 & 0.0822 & 0.157 & 0.0922 & This study \\
\hline Azospira sp. I13 (ISO_OTU 03) & clade II & $17.9 \pm 2.4$ & $2.10 \pm 0.26$ & 8.53 & 0.159 & 0.259 & 0.210 & This study \\
\hline Flavobacterium sp. & clade II & - & 0.5 & - & - & - & - & 76 \\
\hline Dechloromonas aromatica $\mathrm{RCB}$ & clade II & $7.748 \pm 0.57^{*}$ & $0.324 \pm 0.078$ & 23.9 & 0.182 & - & - & 23 \\
\hline Anaeromyxobacter dehalogenans $2 \mathrm{CP}-\mathrm{C}$ & clade II & $0.287 \pm 0.040^{*}$ & $1.34 \pm 0.35$ & 2.14 & 0.00762 & - & - & 23 \\
\hline Alicycliphilus denitrificans I51 (ISO_OTU 04) & clade I & $3.78 \pm 2.29$ & $8.98 \pm 1.83$ & 0.421 & n.d. ${ }^{* * *}$ & 0.0910 & 0.180 & This study \\
\hline Shewanella loihica PV-4 & clade I & $7.49 \pm 0.40^{*}$ & $7.07 \pm 1.13$ & 1.06 & 0.0892 & - & - & 23 \\
\hline Pseudomonas stutzeri DCP-Ps1 & clade I & $69.9 \pm 7.4^{*}$ & $35.5 \pm 9.3$ & 1.96 & 0.326 & - & - & 23 \\
\hline Paracoccus denitrificans & clade I & - & 5 & - & - & - & - & 77 \\
\hline Pseudomonas denitrificans & clade I & - & $30-60$ & - & - & - & - & 78 \\
\hline Pseudomonas aeruginosa & clade I & - & 100 & - & - & - & - & 79 \\
\hline Bradyrhizobium japonicum & clade I & 0.085 & - & - & - & - & - & 80 \\
\hline Paracoccus denitrificans & clade I & $2.33-2.89$ & - & - & - & - & - & 81 \\
\hline
\end{tabular}

* Converted using the 0.28 pg dry-weight per bacterial cell (Madigan and Martinko, 2006)

** Attained dividing $V_{\max } \times 10^{-9}$ by $K_{\mathrm{m}, \mathrm{N} 2 \mathrm{O}}$

*** n.d. represents no growth. 